UNIVERSIDADE DE SÃO PAULO

ESCOLA DE EDUCAÇÃO FÍSICA E ESPORTE

\title{
INFLUÊNCIA DOS TREINAMENTOS DE FORÇA E DE POTÊNCIA NAS ADAPTAÇÕES NEURAIS, MORFOLÓGICAS E NA FUNCIONALIDADE EM IDOSOS
}

Lilian França Wallerstein

SÃo PAULO

2009 
INFLUÊNCIA DOS TREINAMENTOS DE FORÇA E DE POTÊNCIA NAS ADAPTAÇÕES NEURAIS, MORFOLÓGICAS E NA FUNCIONALIDADE EM IDOSOS

LILIAN FRANÇA WALLERSTEIN

\begin{abstract}
Dissertação apresentada à Escola de Educação Física e Esporte da Universidade de São Paulo, como requisito parcial para a obtenção do grau de Mestre em Educação Física.
\end{abstract}

ORIENTADOR: PROF. DR. CARLOS UGRINOWITSCH 


\section{Wallerstein, Lilian França}

Influência dos treinamentos de força e potência nas

adaptações neurais morfológicas e na funcionalidade de

idosos / Lilian França Wallerstein. -- São Paulo : [s.n.], 2010.

xiii, 76p.

Dissertação (Mestrado) - Escola de Educação Física e Esporte da Universidade de São Paulo.

Orientador: Prof. Dr. Carlos Ugrinowitsch

1. Treinamento de força 2. Potência 3. Idosos 4. Sarcopenia I. Título. 


\section{AGRADECIMENTOS}

Em primeiro lugar, agradeço ao Pai maior; àquele que tem colocado em meu caminho pessoas formidáveis e ótimas oportunidades;

Aos meus pais, Eugênio e Helena Wallerstein pelo amor, dedicação, e pelos valores a mim transmitidos, entre eles a busca pelo conhecimento, que foi uma das motivações para esse trabalho;

Ao Lincoln, que me faz perceber o indivíduo de uma maneira diferente, pelo seu amor e por me mostrar que amar não é tão ameaçador quanto eu imaginava;

Ao Luciano Russo, pela fundamental ajuda de bastidores, na aplicação dos treinos e, principalmente, pela amizade;

Ao Renato Barroso, por permitir a tradução estatística dos meus resultados, por me ajudar a interpretá-los, pela paciência em ler meus textos e, sobretudo, por se tornar um verdadeiro parceiro;

Ao Mauro Batista, por me dar a primeira oportunidade de escrever um artigo e, principalmente, pela sua amizade e orientação nos momentos em que minha inexperiência me angustiava;

Ao Hamilton Roschel, pelos sábios conselhos durante o decorrer desse mestrado, pela ajuda nos bastidores, pelo carinho e amizade;

Ao Gilberto Laurentino, por abrir as portas para a realização das ressonâncias, por sua atenção e pela paciência;

Ao Eduardo Souza, meu "irmão", por dividir comigo os momentos de angústias e estresse; 
À Ceres, Ronaldo e Silvio pela fundamental ajuda na aplicação dos treinos e pela paciência com os meus queridos voluntários;

Ao Prof. Dr. Carlos Ugrinowitsch, meu orientador, por me desafiar continuamente e exigir sempre o meu melhor, contribuindo fundamentalmente para a minha formação;

À Ivelise, pela grande ajuda no processo de recrutamento dos voluntários;

Aos meus queridos voluntários, que dedicaram seu tempo, que se envolveram com o projeto, que confiaram em mim e na equipe e, principalmente, que me confirmaram a teoria de que envelhecer de maneira ativa e saudável é muito prazeroso. Sem eles não haveria motivo para tal pesquisa;

Ao Prof. Dr. Marco Túlio de Mello e ao Instituto do Sono da Universidade Federal de São Paulo (UNIFESP), por terem viabilizado a execução desse projeto em uma das melhores estruturas de São Paulo.

À Fundação de Amparo à Pesquisa do Estado de São Paulo (FAPESP), pelo suporte financeiro ao projeto. 


\section{SUMÁRIO}

Página

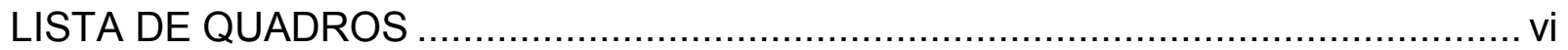

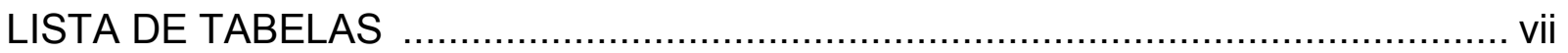

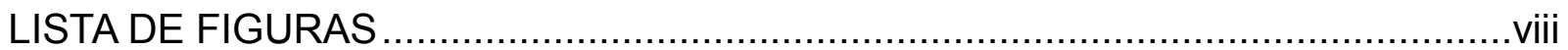

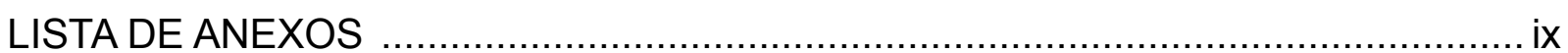

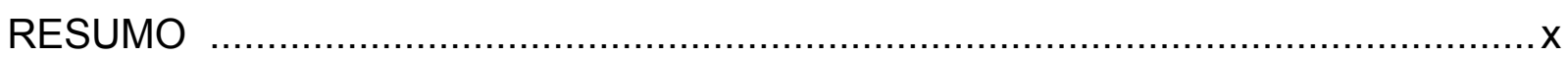

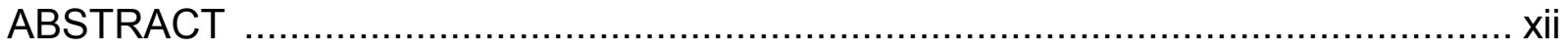

1 INTRODUÇÃO

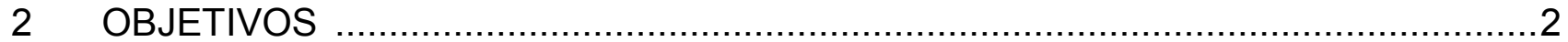

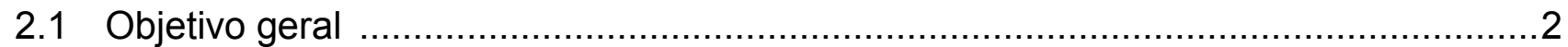

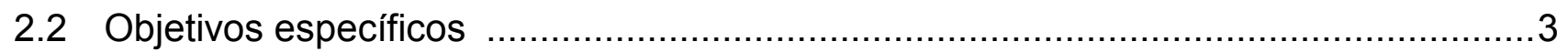

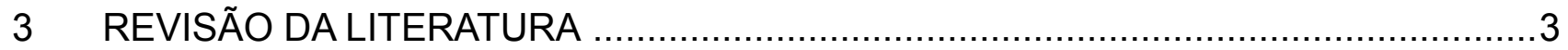

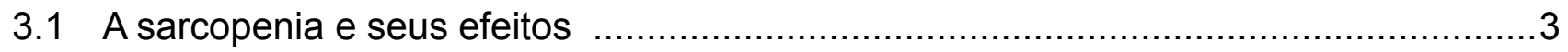

3.1.1 Alterações na morfologia muscular ................................................................

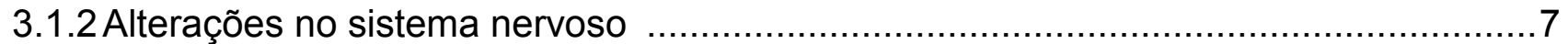

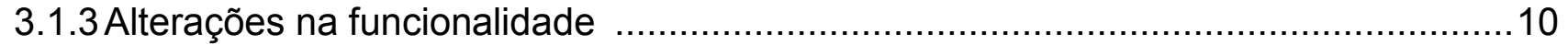

3.2 Adaptações aos treinamentos de força e potência em idosos ................................12

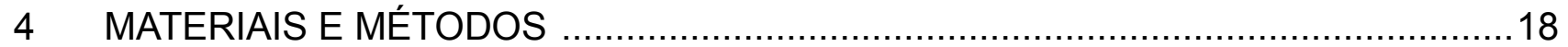

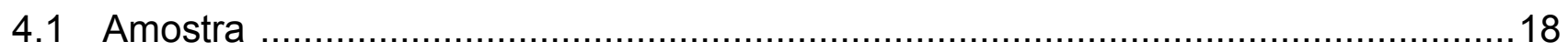

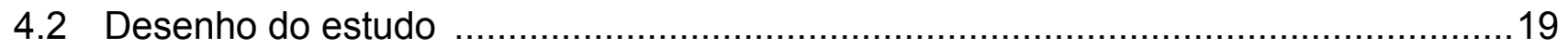

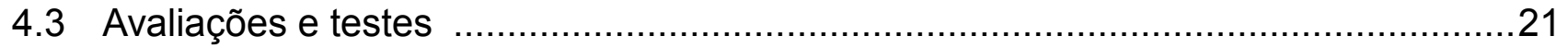

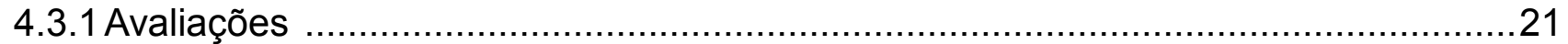

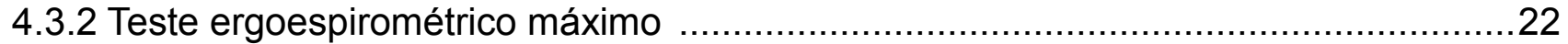

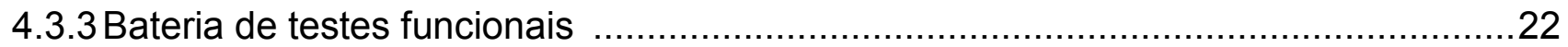

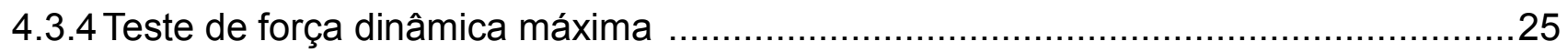

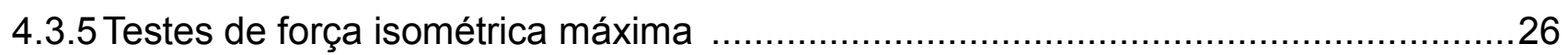

4.3.6 Ativação neural, retardo eletromecânico e taxa de desenvolvimento de força ..........27

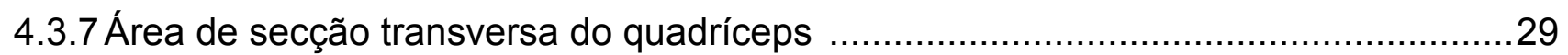

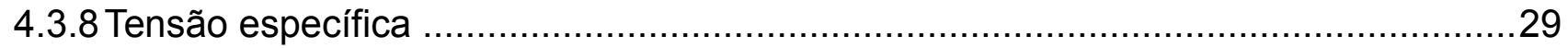


Página

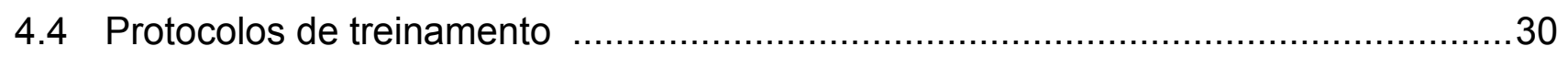

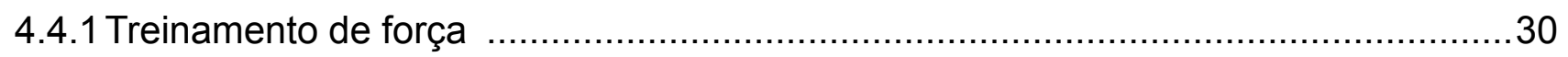

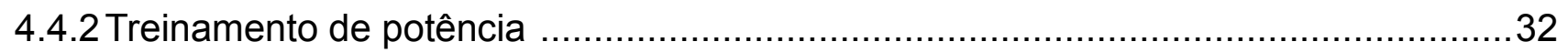

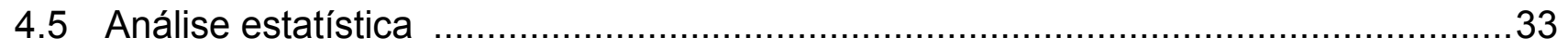

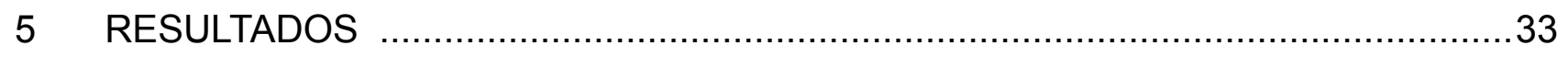

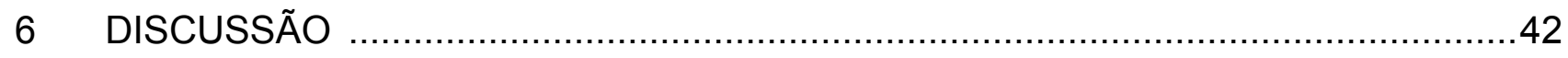

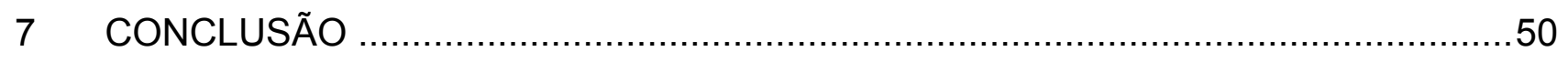

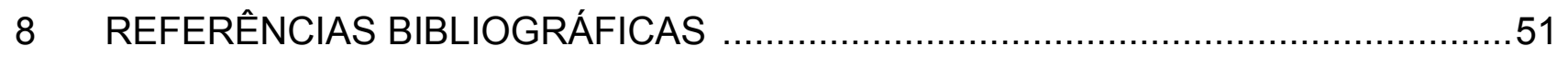

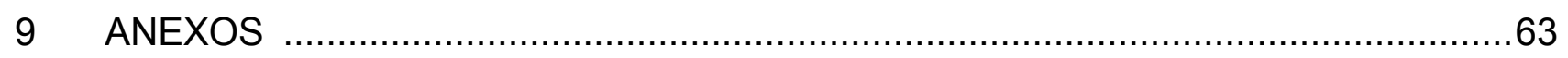




\section{LISTA DE QUADROS}

Página

QUADRO 1 - Desenho do estudo. 21 


\section{LISTA DE TABELAS}

Página

TABELA 1 - Periodização do treinamento de força ao longo de 16 semanas.

TABELA 2 - Periodização do treinamento de potência ao longo de 16 semanas.

TABELA 3 - Características iniciais da amostra nos grupos controle (GC), força (GF) e potência (GP), média ( $\pm \mathrm{DP})$.

TABELA 4 - Amplitude do sinal eletromiográfico (RMS) nos 500 ms antes e após o pico de torque na CVIM nos músculos vasto medial (VM) e vasto lateral (VL) pré e pós treino para os grupos controle (GC), força (GF) e potência $(G P)$, média $( \pm D P)$.

TABELA 5 - Amplitude do sinal eletromiográfico (RMS) nos 500 ms antes e após o pico de torque na CVIBM nos músculos vasto medial (VM) e vasto lateral (VL) pré e pós treino para os grupos controle (GC), força (GF) e potência $(\mathrm{GP})$, média $( \pm \mathrm{DP})$.

TABELA 6 - Retardo eletromecânico (REM) nos músculos vasto medial (VM) e vasto lateral (VL) pré e pós treino para os grupos controle (GC), força (GF) e potência (GP), média ( $(\mathrm{DP})$.

TABELA 7 - Resultados dos testes funcionais de acordo com o grupo de treinamento pré e pós intervenção para os grupos controle (GC), força (GF) e potência (GP), média ( $\pm D P$ ). 


\section{LISTA DE FIGURAS}

\section{Página}

FIGURA 1 - Força dinâmica máxima $(\mathrm{Kg})$ no leg press $(\mathrm{A})$ e no chest press $(\mathrm{B})$ para os grupos controle $(\mathrm{GC})$, força $(\mathrm{GF})$ e potência $(\mathrm{GP})$ pré e pós treino.

FIGURA 2 - Área de seç̧ão transversa da região medial do músculo quadríceps femural (AST, $\mathrm{mm}^{2}$ ) da coxa esquerda (A) e da coxa direita (B) para os grupos controle (GC), força (GF) e potência (GP) pré e pós treino.

FIGURA 3 - Tensão especifica $\left(\mathrm{N} \cdot \mathrm{m} \cdot \mathrm{mm}^{2}{ }^{-1}\right)$ para os grupos controle $(G C)$, força (GF) e potência (GP) pré e pós treino.

FIGURA 4 - Torque isométrico máximo $(\mathrm{N} \cdot \mathrm{m})$ em CVIM para os grupos controle $(\mathrm{GC})$, força (GF) e potência (GP) pré e pós treino.

FIGURA 5 - Torque isométrico balístico máximo $(\mathrm{N} \cdot \mathrm{m})$ em CVIBM para os grupos controle (GC), força (GF) e potência (GP) pré e pós treino. 


\section{LISTA DE ANEXOS}

Página

ANEXO I - Termo de consentimento informado.

.63

ANEXO II - Mini exame do estado mental.

.68

ANEXO III - Escala geriátrica de depressão.

ANEXO IV - Avaliação médica (anamnese). 


\title{
RESUMO
}

\section{INFLUÊNCIA DOS TREINAMENTOS DE FORÇA E DE POTÊNCIA NAS ADAPTAÇÔES NEURAIS, MORFOLÓGICAS E NA FUNCIONALIDADE EM IDOSOS.}

\author{
Autora: Lilian França Wallerstein \\ Orientador: Prof. Dr. Carlos Ugrinowitsch
}

Apesar das perdas provocadas pela sarcopenia, o sistema neuromuscular do idoso ainda mantém parte da sua plasticidade. No entanto, as adaptações promovidas pelos treinamentos de força (TF) e de potência (TP) não foram totalmente elucidadas, assim como se existem diferenças entre essas adaptações nessa população. Para responder tais questões, 43 idosos (63,8 \pm 4,0 anos; 67,2 $\pm 13,4 \mathrm{~kg}$ e $160,2 \pm 8,4 \mathrm{~cm}$ ), inexperientes em treinamento com pesos e independentes participaram desse estudo. Os voluntários foram distribuídos em três grupos: GF (n= $14 ; 70$ a $90 \%$ de $1 \mathrm{RM})$, GP ( $n=16 ; 30$ a $50 \%$ de 1RM) e GC ( $n=13$, não treinou). Durante 16 semanas o GF e o GP realizaram duas sessões de treino semanalmente. Os resultados significantes foram: aumento de $42,7 \%$ em GF e $33,8 \%$ em GP no teste de 1RM (leg press) e 31\% em GF e 25,4\% em GP (chest press); aumento de 6\% em GF e 3,6\% em GP na ASTq; aumento de 22,4\% em GF e 17,1\% em GP na CVIM e uma diminuição de $28 \%$ em GF e $32 \%$ em GP no REM. Não houve diferenças significativas entre GF e GP nas variáveis analisadas. Nenhum dos grupos apresentou aumento no sinal eletromiográfico nem na TDF. Não houve 
alteração significativa na funcionalidade. Portanto, ainda que com características distintas, o TF e o TP são similares em relação às adaptações analisadas, equiparando-se como estratégias de treinamento eficazes no combate à sarcopenia e seus efeitos.

Palavras-chave: taxa de desenvolvimento de força, área de secção transversa, força isométrica máxima. 


\title{
ABSTRACT \\ COMPARISON BETWEEN STRENGTH AND POWER TRAINING ON NEURAL, MORPHOLOGICAL AND FUNCTIONAL ADAPTATIONS IN THE ELDERLY.
}

\author{
Author: Lilian França Wallerstein \\ Adviser: Prof. Dr. Carlos Ugrinowitsch
}

In spite of sarcopenia-induced losses, elderly people's neuromuscular system keeps its plasticity. However, strength and power training-induced adaptations have not been completely elucidated. It also unknown if these adaptations are related to elderly functionality. Fourty three healthy and independent old men and women (63.8 $\pm 4.0 \mathrm{yrs} ; 67.2 \pm 13.4 \mathrm{~kg}$ e $160.2 \pm 8.4 \mathrm{~cm}$ ) with no resistance training experience volunteered for this study. Participants were randomly distributed into three groups: GF $(n=14 ; 70-90 \%-1 R M), G P(n=16 ; 30-50 \%-1 R M)$ e GC $(n=13$, no training). GF and GP trained twice a week for 16 weeks. Leg-press (42.7\% in GF and $33.8 \%$ in GP) and chest-press 1-RM ( $31 \%$ in GF and $25.4 \%$ in GP), quadriceps cross sectional area (6\% in GF and $3.6 \%$ in GP), maximal voluntary isometric contraction $(22.4 \%$ in GF and $17.1 \%$ in GP) were significantly increased in both groups. Electromechanical delay decreased $28 \%$ in GF and $32 \%$ in GP. There were no significant differences between groups. EMG and rate of force development did not change throughout the training period. Only main effect of time was observed for the functional tests. These results suggest that even with different characteristics, both strength and power 
training induce similar neuromuscular adaptations. Thus, both training regimens are equally effective in preventing and treating sarcopenia.

Keywords: rate of force development, cross sectional area, maximal isometric force. 


\section{INTRODUÇÃO}

A sarcopenia, ou perda progressiva de massa muscular, se inicia por volta dos 30 anos de idade e é agravada após os 60 anos, tornando-se mais evidente a medida em que o processo de envelhecimento se desenvolve (LEXELL, TAYLOR \& SJOSTROM, 1988). Ela é ocasionada por um conjunto de alterações dentre as quais as neurais (diminuição da ativação muscular, do número de motoneurônios, da coordenação intermuscular), morfológicas (alteração de fenótipo e de volume das fibras musculares) e comportamentais (redução no nível de atividade física e mudanças nutricionais). Sua principal consequência é a diminuição da função muscular, pois altera o equilíbrio, a força, a velocidade dos movimentos que, em conjunto, geram um quadro de fraqueza, lentidão e diminuição da funcionalidade (IZQUIERDO, AGUADO, GONZALEZ, LOPEZ \& HAKKINEN, 1999; DOHERTY, 2003).

Especificamente, a funcionalidade é a capacidade de executar as atividades da vida diária (AVDs) de maneira independente. Tarefas simples como levantar de uma cadeira, subir escadas, pegar o ônibus, carregar uma sacola e até mesmo andar alguns metros tornam-se desafiadoras, dependendo do estado funcional da pessoa idosa. Assim, a redução da funcionalidade compromete a mobilidade do indivíduo, aumentando os riscos de quedas e fraturas e piorando a qualidade de vida. Porém, apesar das alterações negativas decorrentes do processo de sarcopenia, 0 organismo ainda pode adaptar-se em decorrência da prática adequada de exercícios físicos.

De fato, o treinamento de força (TF) mostrou combater os efeitos negativos da sarcopenia, aumentando a força e a massa muscular, e melhorando a ativação neural e a coordenação muscular, em populações muito idosas e até mesmo frágeis (FRONTERA, MEREDITH, O'REILLY, KNUTTGEN \& EVANS, 1988; FIATARONE, MARKS, RYAN, MEREDITH, LIPSITZ \& EVANS, 1990; HAKKINEN, KRAEMER, NEWTON \& ALEN, 2001; SUETTA, AAGAARD, ROSTED, JAKOBSEN, DUUS, KJAER \& MAGNUSSON, 2004). Contudo, apesar dos ganhos na massa muscular, na força e nas adaptações neurais promovidas pelo TF, estas melhorias não parecem ser suficientes para diminuir a deficiência de idosos, durante a execução das AVDs 
(EARLES, JUDGE \& GUNNARSSON, 2001). Especula-se que a ausência de transferência das adaptações do TF para a melhoria da funcionalidade aconteça pelo fato deste não ser realizado com velocidade, uma vez que esta capacidade é fundamental para a realização das AVDs (HENWOOD, RIEK \& TAAFFE, 2008).

Sendo assim, mais recentemente passou-se a empregar o TP com o intuito de melhorar a funcionalidade em idosos, uma vez que uma das principais características desse tipo de programa é a execução dos exercícios em alta velocidade. Existem indícios de que o TP possa ser mais eficiente em ativar as unidades motoras de característica rápida (as de alto limiar) além dos maiores efeitos na taxa de desenvolvimento de força (TDF), essas adaptações parecem ser mais específicas à realização das AVDs (VAN CUTSEM, DUCHATEAU \& HAINAUT, 1998; HAKKINEN et al., 2001; KYROLAINEN, AVELA, MCBRIDE, KOSKINEN, ANDERSEN, SIPILA, TAKALA \& KOMI, 2005).

A comparação entre os treinamentos de força e potência em idosos é algo recente na literatura. Por isso, o número de estudos que abordam essa temática ainda é pequeno (MISZKO, CRESS, SLADE, COVEY, AGRAWAL \& DOERR, 2003; BOTTARO, MACHADO, NOGUEIRA, SCALES \& VELOSO, 2007; HENWOOD et al., 2008) e, no nosso conhecimento, não há estudos que comparam as adaptações neuromusculares produzidas pelo TF e pelo TP em idosos. Há comparações apenas quanto às melhorias na funcionalidade (MISZKO et al., 2003; HENWOOD et al., 2008). Com isso, comparar as adaptações neuromusculares produzidas pelo TF e pelo TP torna-se importante, pois os exercícios utilizados devem melhorar tanto a funcionalidade quanto a morfologia e a função muscular de idosos.

\section{OBJETIVOS}

\subsection{Objetivo geral}

Comparar os efeitos dos treinamentos de força e de potência na força máxima, na massa muscular, na taxa de desenvolvimento de força e na ativação neuromuscular de idosos; avaliar se essas adaptações diferem de acordo com o tipo de treinamento e se elas podem estar associadas à melhora da funcionalidade nessa população. 


\subsection{Objetivos específicos}

a) Comparar as respostas da força máxima dinâmica e isométrica produzidas pelos treinamentos de força e potência;

b) Comparar a resposta da área de secção transversa do músculo quadríceps femural promovida pelos treinamentos de força e potência;

c) Comparar as respostas na tensão específica produzidas pelos treinamentos de força e potência;

d) Comparar as alterações na taxa de desenvolvimento de força produzidas pelos treinamentos de força e potência;

e) Comparar as mudanças na amplitude do sinal eletromiográfico (RMS) produzidas pelos treinamentos de força e potência;

f) Comparar as alterações no retardo eletromecânico (electrical mechanical delay - REM) produzidas pelos treinamentos de força e potência;

g) Comparar as mudanças na funcionalidade produzidas pelos treinamentos de força e potência.

\section{REVISÃO DA LITERATURA}

\subsection{A sarcopenia e seus efeitos}

\subsubsection{Alterações na morfologia muscular}

A queda da força e da potência, acontecimentos evidentes durante 0 envelhecimento, parece estar relacionada, entre outros fatores, com as alterações morfológicas que ocorrem na musculatura esquelética de pessoas idosas. Esse processo, definido por alguns autores como sarcopenia, é caracterizado pela diminuição da massa muscular, que pode ser o resultado da diminuição do número e/ou tamanho das fibras musculares (tipo I e tipo II) (DOHERTY, 2003). Dentre os subtipos de fibras musculares, as do tipo II, que são aquelas com maior capacidade de gerar tensão e velocidade de encurtamento, são as mais atingidas pela 
sarcopenia (IZQUIERDO et al., 1999). No músculo vasto lateral, por exemplo, durante o processo de envelhecimento, as fibras do tipo II passam de $60 \%$ em adultos jovens para 30\% em homens sedentários com mais de 80 anos (LARSSON, 1983). Contudo, atualmente, o termo sarcopenia é usado para descrever as alterações que ocorrem na musculatura esquelética em decorrência de modificações no sistema nervoso central e periférico, no sistema endócrino, no sistema imunológico, no consumo calórico e protéico, na capacidade dos tecidos em utilizar os macronutrientes, assim como na redução no nível de atividade física diária, tratando-se, portanto, de um processo multifatorial e responsável pelo quadro de fraqueza muscular muitas vezes presente no idoso (KIM, WILSON \& LEE, 2010 ; MORLEY, BAUMGARTNER, ROUBENOFF, MAYER \& NAIR, 2001; DOHERTY, 2003).

A sarcopenia tem prevalência maior que $30 \%$ entre aqueles com mais de 60 anos e tende a aumentar uma vez que a população idosa continua crescendo mundialmente (DOHERTY, 2003). Contudo, existem evidências de que esse processo não começa quando o indivíduo se torna idoso. O estudo de LEXELL et al. (1988) analisou a área de secção transversa do músculo vasto lateral de 43 cadáveres do sexo masculino (15 a 83 anos) e concluiu que a atrofia muscular tem início por volta dos 25 anos e, após essa idade, o processo tende a acelerar, atingindo o pico de velocidade após os 60 anos. Ainda, entre os 20 e 80 anos há uma redução de cerca de $40 \%$ na área de secção transversa do músculo vasto lateral. Os autores completam o estudo sugerindo que essa redução é causada principalmente pela perda de fibras do tipo II (morte celular) e, em menor proporção, pela atrofia das fibras musculares em geral, indicando uma seletividade no processo de perda de massa muscular.

Adicionalmente, a produção de força está diretamente relacionada à área de secção transversa (AST) do músculo (THOMPSON, 1994). No entanto, alguns estudos sugerem que a perda de força não é totalmente explicada pela redução na AST (OVEREND, CUNNINGHAM, KRAMER, LEFCOE \& PATERSON, 1992; JUBRIAS, ODDERSON, ESSELMAN \& CONLEY, 1997; FRONTERA, SUH, KRIVICKAS, HUGHES, GOLDSTEIN \& ROUBENOFF, 2000). Eles sugerem que mudanças na tensão específica (força/AST), uma medida mais qualitativa da função 
muscular, também contribuem para a redução da força com a idade. Segundo JUBRIAS et al. (1997), a redução da AST é acompanhada por mudanças no recrutamento muscular e na funcionalidade do aparato contrátil (despolarização do sarcolema, transmissão do potencial através dos túbulos transversos, liberação e recaptação do cálcio) que, por fim, reduzem a tensão específica. Nesse sentido, MACALUSO, NIMMO, FOSTER, COCKBURN, MCMILLAN e DE VITO (2002) observaram que a tensão específica dos extensores e flexores do joelho de idosas era $20,4 \%$ e 42,7\% menores em relação às jovens.

Além da redução na produção de força, a potência muscular também é diminuída devido às alterações que ocorrem com as fibras do tipo II. Essas fibras são menos resistentes à fadiga em relação às fibras do tipo I. Porém, a tensão específica dessas fibras é maior do que a das fibras do tipo I devido a uma maior quantidade de pontes cruzadas de miosina-actina, capacitando-as a gerar mais força (THOMPSON, 1994). Ainda, em estudo com ratos, foi observada maior atividade da ATPase nas fibras do tipo II, Ihes conferindo maior velocidade de contração (BOTTINELLI, CANEPARI, REGGIANI \& STIENEN, 1994). Além da redução da população e do tamanho dessas fibras ao longo do processo de envelhecimento, há evidências de que a redução da força e da potência também está relacionada a alterações no funcionamento do retículo sarcoplasmático (RS) (THOMPSON, 1994). Segundo LARSSON e SALVIATI (1989), dois prováveis fatores responsáveis pela diminuição da velocidade de contração são a diminuição da função do RS e também a redução de seu volume, principalmente nas fibras do tipo II.

O declínio da potência começa a partir dos quarenta anos (KOSTKA, 2005). Essa perda pode ter grande repercussão na funcionalidade quando o indivíduo tornar-se idoso (DE VOS, SINGH, ROSS, STAVRINOS, ORR \& FIATARONE SINGH, 2005), pois para a realização das AVDs, além de força é necessário que ela seja produzida rapidamente (MAKI \& MCILROY, 2006). A queda anual de potência chega à ordem de 3,5\% após o 60 anos (SKELTON, GREIG, DAVIES \& YOUNG, 1994; FIELDING, LEBRASSEUR, CUOCO, BEAN, MIZER \& FIATARONE SINGH, 2002), enquanto que a da força é de 1 a $2 \%$ ao ano (SKELTON et al., 1994). A redução da potência também está associada à diminuição da taxa de desenvolvimento de força (TDF), uma vez que esta indica a velocidade em que a força é capaz de ser gerada. 
Por isso, a TDF é uma capacidade fundamental para a realização das AVDs, tais como responder rápido a um desequilíbrio e atravessar rapidamente uma rua. IZQUIERDO et al. (1999) observaram que homens por volta dos 70 anos apresentaram valores de TDF 64\% menores que homens por volta dos 20 anos, e correlacionaram esse resultado ao maior tempo de resposta no reposicionamento do corpo após uma perturbação, em um teste de equilíbrio. Esses dados sugerem que baixos valores de TDF podem levar o idoso, por exemplo, a uma menor capacidade de aceleração de um segmento corporal e de manutenção do equilíbrio que, em conjunto, diminuem a estabilidade entre os idosos (CLOSE, 2005; MAKI \& MCILROY, 2006).

Outra alteração observada nas fibras do tipo II consiste na população de células satélites (CS) presente nessas fibras. As CS estão diretamente relacionadas à capacidade regenerativa do músculo esquelético. Essas células são as precursoras das fibras musculares e têm papel fundamental no controle do número de mionúcleos (KADI, CHARIFI, DENIS \& LEXELL, 2004). Consequentemente, também controlam o domínio mionuclear, ou seja, à razão entre o número de mionúcleos e a área da fibra muscular. VERDIJK, KOOPMAN, SCHAART, MEIJER, SAVELBERG e VAN LOON (2007) ressaltaram que as fibras do tipo II de homens idosos continham uma menor concentração de CS em relação aos jovens, o que indicaria, segundo os autores, uma menor capacidade regenerativa das células musculares em idosos. Embora não tenham feito a contagem por tipo de fibra muscular, KADI et al. (2004) também notaram a redução de CS em idosos de ambos os sexos. Esses autores complementam que embora o número de CS seja menor do que nos jovens, o número de mionúcleos por fibra muscular era aumentado nos idosos. Talvez, o aumento da razão núcleo/citoplasma seja a justificativa para a continuidade da resposta hipertrófica (embora menor que em jovens), mesmo durante o envelhecimento.

Alguns autores sugeriram que as evidências até então não são suficientes para atribuir a diminuição da capacidade regenerativa do músculo esquelético do idoso somente à redução no número de CS (KADI et al., 2004; VERDIJK et al., 2007). Sabe-se que não são apenas as alterações na morfologia muscular as responsáveis pela redução das capacidades de força e potência. As modificações que ocorrem nos 
sistema nervoso também contribuem para as alterações no tamanho e na quantidade das fibras do tipo II e, consequentemente, para a diminuição da funcionalidade no idoso (VANDERVOORT, 2002; DOHERTY, 2003). Uma vez que o movimento depende, dentre outros fatores, da interação entre os sistemas muscular e nervoso, principalmente no que se refere ao recrutamento adequado das unidades motoras (FLECK \& KRAEMER, 2006), faz-se necessário entender essa interação para assim melhor compreender como esse conjunto de alterações contribui para a diminuição da funcionalidade do idoso.

\subsubsection{Alterações no sistema nervoso}

Assim como o sistema muscular, o sistema nervoso também sofre alterações durante o processo de envelhecimento. Dentre elas, as mudanças nos motoneurônios (MNs) e na ativação das unidades motoras (UMs).

A unidade motora é composta por um motoneurônio alfa, pela placa motora (junção entre a ramificação terminal do motoneurônio e a fibra muscular) e por todas as fibras musculares inervadas por um mesmo motoneurônio (DOHERTY, VANDERVOORT \& BROWN, 1993). O córtex motor primário gera disparos elétricos com frequência e magnitude definidas. Esses disparos percorrem o MN até atingir a placa motora, desencadeando a contração da fibra muscular. As UMs são recrutadas de acordo com seu tamanho e capacidade de produção de força, sendo que as menores, que têm limiares de ativação e capacidade de produção de força mais baixos, são recrutadas primeiro, passando para as unidades motoras com limiar de ativação e capacidade de produção de força maiores (princípio do tamanho) (HENNEMAN, 1985). Sendo assim, de acordo com a frequência e magnitude do sinal transmitido pelo $\mathrm{MN}$, são determinadas a quantidade e a velocidade em que a força é produzida. Portanto, os motoneurônios são as estruturas que fazem a ligação entre o sistema nervoso central e o sistema muscular. Como o desempenho neuromuscular não é determinado apenas pelo volume dos músculos envolvidos, mas também pela habilidade do sistema nervoso em recrutá-los apropriadamente (MORITANI, 1993), a interação entre esses dois sistemas é fundamental para que haja movimento. Da mesma maneira que ocorre no sistema muscular, mudanças estruturais, funcionais e 
bioquímicas acompanham o envelhecimento do sistema nervoso (VERDU, CEBALLOS, VILCHES \& NAVARRO, 2000).

Há indícios de perdas de motoneurônios alfa que podem comprometer cerca de metade das UMs presentes em adultos jovens (MATTIELLO-ZVERZUT, 2003). O estudo de TOMLINSON e IRVING (1977) é um dos pioneiros a respeito do número de MNs que inervam os músculos de humanos de diferentes idades. Os autores examinaram a região lombosacral 47 cadáveres de indivíduos entre os 13 e os 95 anos de idade. Até os 60 anos não foram encontradas alterações no número total de MNs. Porém, após essa faixa etária alguns indivíduos apresentaram apenas $50 \%$ do número de MNs de indivíduos jovens. Também foi observada uma atrofia dos axônios, que tem como consequência a queda da velocidade de condução do impulso neural (VERDU et al., 2000), aumentando, por exemplo, o tempo de reação a um determinado estímulo, uma vez que a resposta eferente deve percorrer esses axônios. Parece que a atrofia do axônio está relacionada com uma diminuição do fluxo sanguíneo, que causa uma redução na disponibilidade de oxigênio e glicose, prejudicando o metabolismo oxidativo e atenuando a produção mitocondrial de ATP, essencial para o funcionamento da bomba de sódio e potássio, responsável pelo mecanismo de despolarização e repolarização da membrana do axônio (VERDU et al., 2000). Essas alterações em conjunto podem explicar a aparente redução da excitabilidade dos MNs (ROOS, RICE \& VANDERVOORT, 1997) e o aumento da irregularidade da frequência de disparos das UMs com o envelhecimento (MORLEY et al., 2001).

Uma das consequências da redução do número MNs é a alteração expressiva da quantidade de UMs durante o envelhecimento (ROOS et al., 1997). Em decorrência da morte de MNs em idosos, várias fibras musculares ficarão denervadas. Contudo, os MNs restantes re-inervam a parte fibras musculares denevardas (ROOS et al., 1997). Contudo, esse processo de re-inervação é feito, na maioria das vezes, por motoneurônios de característica lenta, com menor frequência de disparo (MATTIELLO-ZVERZUT, 2003). Ou seja, se uma fibra do tipo II (rápida) sofrer denervação e for re-inervada por um MN tônico, essa fibra passará a ter características de fibra tipo I (lenta) e uma das conseqüências desse processo é a diminuição da TDF. 
A TDF está relacionada diretamente à frequência de disparos das UMs (VAN CUTSEM et al., 1998). Para que a TDF seja maximizada é necessário que as UMs, principalmente as de alto limiar (aquelas que são mais velozes), sejam ativadas rapidamente e com uma elevada frequência de disparo. No entanto, a frequência de disparos das UMs não é a única variável que interfere na TDF. A distribuição dos diferentes tipos de fibras, a quantidade de massa muscular (BARRY, WARMAN \& CARSON, 2005) e a sincronia entre as UMs (RICARD, UGRINOWITSCH, PARCELL, HILTON, RUBLEY, SAWYER \& POOLE, 2005), assim como a relação agonista/antagonista (SALE, 1988) também são fatores que interferem na TDF. O treinamento de força é capaz de aumentar a TDF, mesmo em indivíduos idosos (AAGAARD, MAGNUSSON, LARSSON, KJAER \& KRUSTRUP, 2007). No entanto, o treino de potência também é capaz de promover adaptações neurais bastante eficientes, que aumentam a TDF (KYROLAINEN et al., 2005) como a diminuição do limiar de ativação, aumento da frequência inicial de disparo e de ocorrência de doublets (descargas duplas produzidas em intervalos menores que $5 \mathrm{~ms}$ ) nas unidades motoras (VAN CUTSEM et al., 1998).

Embora as alterações decorrentes do processo de envelhecimento sejam inevitáveis, estudos realizados desde a década de 80 , têm demonstrado que os treinamentos de força e de potência muscular podem atenuar esse processo e revertê-lo parcialmente (FRONTERA et al., 1988; FIATARONE et al., 1990; HAKKINEN et al., 2001; MISZKO et al., 2003; HENWOOD et al., 2008). O fruto desses estudos são evidências de que mesmo com tantas alterações negativas, a maioria dos idosos é capaz de melhorar a ativação de suas unidades motoras a fim de aumentar a produção de força (DOHERTY, 2003) e a velocidade de movimento (HAKKINEN, ALEN, KALLINEN, IZQUIERDO, JOKELAINEN, LASSILA \& MALKIA, 1998; BARRY et al., 2005). Atualmente se desconhece como ocorre a progressão dos fatos: se o evento primário na produção da sarcopenia é decorrente da perda de fibras musculares com subsequente morte neuronal retrógrada, ou ao contrário. 


\subsubsection{Alterações na funcionalidade}

A diminuição da funcionalidade é uma das principais consequências das alterações que ocorrem durante o envelhecimento. Um dos seus principais efeitos é a ocorrência de quedas entre idosos, que é de 33\% após os 65 anos, chegando a $50 \%$ após os 80 anos de idade (TINETTI \& WILLIAMS, 1997). Estas, por sua vez, podem levar os idosos a longos períodos de internação, aumentando a morbidade e, consequentemente, os gastos com a saúde. Por conta disso, são consideradas as principais causadoras de morte nessa população (STEVENS, 2005).

Com o objetivo de identificar os fatores associados às quedas em idosos, 0 estudo prospectivo de TINETTI, SPEECHLEY e GINTER (1988) acompanhou 336 idosos (78 $\pm 5,1$ anos) durante um ano. Os autores reportam que pessoas com pouca força nos membros inferiores apresentaram risco 3,8 vezes maior de sofrer quedas do que aquelas que apresentavam mais força e que, aqueles com alguma alteração no equilíbrio e na marcha tinham risco 1,9 vezes maior de cair do que aqueles que não manifestavam tais alterações. Além disso, durante o período do estudo, $32 \%$ da amostra sofreram pelo menos uma queda, $27 \%$ caíram, ao menos três vezes e, $24 \%$ dos que caíram tiveram sérias complicações e $6 \%$ sofreram fraturas.

Além das quedas, a diminuição da força e da potência implica em dificuldades ao realizar tarefas básicas, como levantar de uma cadeira, subir alguns degraus, sair da cama e, até mesmo, se equilibrar. Adicionalmente, o aparecimento das comorbidades (ex: diabetes, hipertensão, obesidade) tendem a acentuar as dificuldades para a realização das tarefas instrumentais da vida diária (AIVDs - fazer compras, cozinhar, lavar roupas, usar o telefone), aumentando ainda mais a dependência desses indivíduos de terceiros. Esses dados evidenciam a necessidade do idoso ter um bom estado funcional para a manutenção e melhoria de sua qualidade de vida. Portanto, medir a funcionalidade na população idosa com o objetivo de diagnóstico e prevenção passou a ser de fundamental importância na avaliação geriátrica.

Frequentemente, a funcionalidade é avaliada através de auto-declaração de dificuldade ou de declaração indicativa de necessidade de ajuda nas AVDs e nas AIVDs. No entanto, estudos (AVLUND, SCHROLL, DAVIDSEN, LOVBORG \& RANTANEN, 1994; GURALNIK, FERRUCCI, SIMONSICK, SALIVE \& WALLACE, 
1995) semelhantes ao de TINETTI et al. (1988) utilizam além dessas declarações, vários testes como ferramentas para identificar a relação entre algumas habilidades e capacidades motoras e o estado funcional em idosos. Nesse sentido, é possível encontrar na literatura vários testes validados e de fácil aplicação que apresentam boa correlação com testes mais complexos (ex: análise cinemática da marcha, teste de 1RM) (ALEXANDER, ULBRICH, RAHEJA \& CHANNER, 1997; VELLAS, WAYNE, ROMERO, BAUMGARTNER, RUBENSTEIN \& GARRY, 1997; SHUMWAY-COOK, BRAUER \& WOOLLACOTT, 2000; ENRIGHT, MCBURNIE, BITTNER, TRACY, MCNAMARA, ARNOLD \& NEWMAN, 2003; WHITNEY, WRISLEY, MARCHETTI, GEE, REDFERN \& FURMAN, 2005). Ainda, esses testes tem alta associação com o risco de quedas e o grau de independência, principalmente em idosos frágeis, tornando-se bons parâmetros para a caracterização do status funcional do idoso. Essas medidas têm mostrado que idosos com baixo desempenho em testes funcionais têm um risco 4,2 a 4,9 vezes maior de desenvolver algum tipo de deficiência em relação àqueles com melhor desempenho nos mesmos testes (GURALNIK et al., 1995). Portanto, podemos considerá-los como importantes ferramentas para a predição do risco de quedas, institucionalização e, até mesmo, de morte (GURALNIK et al., 1995). Através desses testes é possível avaliar as capacidades de força, potência, resistência aeróbia em atividades próximas do que se faz no cotidiano. Os testes "six minute walking test"; "time to up and go", "one leg standing"," rise from the floor"; "rise from the chair five times" estão validados e bem descritos na literatura científica (ALEXANDER et al., 1997; VELLAS et al., 1997; SHUMWAY-COOK et al., 2000; ENRIGHT et al., 2003; WHITNEY et al., 2005). Esses testes são definidos em vários artigos como testes de funcionalidade e equilíbrio. Eles envolvem atividades cotidianas, como caminhar durante um tempo determinado, levantar contornar um obstáculo e sentar, ficar apoiado sobre um pé, levantar do chão, levantar e sentar em uma cadeira. Além disso, esses testes têm mostrado sensibilidade suficiente para detectar o estado funcional do idoso. Uma das mais conhecidas baterias de testes empregada no diagnóstico funcional de grandes grupos de idosos é a bateria de RIKLI (2000). É importante notar que nesses testes/tarefas a força e a velocidade estão envolvidas de alguma maneira, 
evidenciando a importância de um limiar de força e de potência musculares para a realização das tarefas cotidianas de maneira independente.

$\mathrm{Na}$ literatura já são bastante conhecidas as diferentes maneiras de se quantificar as capacidades de força e potência, mas ainda não se sabe exatamente se e como elas são transferidas para as AVDs. Por serem capazes de determinar o estado funcional do idoso e utilizarem tarefas que envolvem certo nível de força e potência, os testes funcionais podem ser úteis também no estudo dos efeitos de diferentes estratégias de treinamento na funcionalidade dessa população, ou seja, na maneira como as adaptações dos distintos tipos de treinamento, incluindo ganhos de força, são transferidas para as AVDs. Isso é o que tem sido feito nos estudos mais recentes dessa área (MISZKO et al., 2003; HENWOOD et al., 2008). Nessa mesma linha de raciocínio, se torna possível investigar a estratégia de treinamento mais adequada para melhora da funcionalidade.

\subsection{Adaptações aos treinamentos de força e potência em idosos}

Embora ainda persistam controvérsias na literatura a respeito dos motivos que levam à sarcopenia e à deficiência funcional, existem fortes evidências de que esse processo pode ser desacelerado em indivíduos que mantêm um estilo de vida ativo (FIATARONE, O'NEILL, RYAN, CLEMENTS, SOLARES, NELSON, ROBERTS, KEHAYIAS, LIPSITZ \& EVANS, 1994; HURLEY \& ROTH, 2000; HAKKINEN et al., 2001; FRONTERA \& BIGARD, 2002; MISZKO et al., 2003; HENWOOD et al., 2008).

Apesar das evidências que indicam a diminuição da capacidade adaptativa com o envelhecimento (KADI et al., 2004; VERDIJK et al., 2007), vários estudos nos quais idosos treinaram com pesos em intensidades relativamente altas (80\% da contração voluntária máxima - CVM), evidenciam boas respostas ao treinamento, corroborando com a idéia de manutenção de parte da plasticidade do sistema neuromuscular (FIATARONE et al., 1990; HAKKINEN, ALEN, KALLINEN, NEWTON \& KRAEMER, 2000; FRONTERA \& BIGARD, 2002). Nesse sentido, alguns autores tem demonstrado que o treinamento de força (TF) é capaz de combater, prevenir ou até mesmo retardar perdas funcionais e fisiológicas do organismo, agindo diretamente nas diferentes frentes que levam o idoso ao quadro de fraqueza e deficiência 
funcional (FRONTERA et al., 1988; FIATARONE et al., 1990; REEVES, NARICI \& MAGANARIS, 2004). Porém, os mecanismos que levam ao aumento da força em idosos não estão totalmente elucidados, uma vez que a força não é só uma propriedade apenas do músculo esquelético. Conforme fora mencionado anteriormente, a produção de força está atrelada também ao sistema nervoso e à interação entre esse e o sistema muscular.

O estudo de FRONTERA et al. (1988) submeteu 12 senhores saudáveis e sedentários, com idade entre 60 e 72 anos, à 12 semanas de TF, com intensidade de $80 \%$ de 1 RM. O treinamento consistia em três séries unilaterais de oito repetições para extensores e flexores do joelho, com frequência de três vezes por semana. Foram avaliados a força dinâmica na cadeira extensora (1RM), os picos de torque isocinético e isométrico, a área de secção transversa (tomografia computadorizada TC), a proporção de fibras lentas e rápidas (biópsia do vasto lateral) e a síntese proteica diária (excreção de histidina). Os autores encontraram aumentos na força dinâmica da ordem de 107,4 e 226,7\% nos extensores e flexores do joelho, respectivamente. O pico de torque isocinético dos extensores do joelho aumentou $8,5 \%$ na perna direita e $10 \%$ na esquerda, à velocidade de $60 \%$ e $14,6 \%$ e $18,5 \%$ nos flexores no lado direito e esquerdo, à velocidade de $240 \%$ s. Já o pico de torque isométrico aumentou somente nos extensores do joelho esquerdo (13\%). Esses ganhos foram atribuídos ao aumento médio de $10,6 \%$ na ASTq, refletidos pelo aumento de $33,5 \%$ na área de fibras do tipo I e de $27,6 \%$ para fibras do tipo II. Adicionalmente foi observado um aumento na síntese diária de proteínas durante o treinamento.

Posteriormente, FIATARONE et al. (1990) publicaram um dos estudos mais citados na literatura, pois foi um dos pioneiros a submeter idosos muito velhos, frágeis e institucionalizados ao TF. A amostra foi composta por seis mulheres e quatro homens com idade entre 86 e 96 anos. A intensidade do treinamento variou entre $50-80 \%$ de 1 RM, com três séries de oito repetições para extensores e flexores do joelho. O programa teve duração de oito semanas e frequência de três vezes por semana. A média do ganho de força no teste de 1RM (na cadeira extensora) foi de $174 \pm 31 \%$ e do aumento da massa muscular total, mensurada por TC, foi de $9 \pm 4,5 \%$, ambos semelhantes aos resultados do estudo de FRONTERA et al. (1988). Porém, o 
diferencial do estudo de FIATARONE et al. (1990) foi a realização de alguns testes funcionais. Os autores reportam que, apesar da manutenção da velocidade habitual da marcha em cinco idosos que conseguiram terminar o teste de marcha relacionada ao equilíbrio (tanden gait speed - caminhar colocando o calcanhar de um pé colado ao hálux do outro pé), a velocidade da marcha na realização desse teste aumentou $48 \%$, passando de $13,8 \mathrm{~cm} \cdot \mathrm{seg}^{-1}$ para $20,4 \mathrm{~cm} \cdot \mathrm{seg}^{-1}$. Adicionalmente, dois idosos deixaram de usar bengalas e um dos três idosos que não conseguia levantar da cadeira sem o auxílio dos braços no início do estudo passou a fazê-lo.

Posteriormente, FERRI, SCAGLIONI, POUSSON, CAPODAGLIO, VAN HOECKE e NARICI (2003) compararam os aumentos da força e potência musculares através do TF. Fizeram parte do estudo 16 homens com idade média de 67,9 0 0,9 anos, fisicamente ativos, porém sem experiência em TF. O treinamento aconteceu três vezes por semana, durante 16 semanas, consistindo em uma série de 10 repetições para os extensores do joelho (EJ) e flexores plantares (FP) com intensidade de $80 \%$ de 1 RM avaliada a cada duas semanas. As variáveis analisadas foram força dinâmica (1RM), o pico de torque isométrico, a potência média, a ASTq e, a inovação desse estudo foi a medida da atividade elétrica dos músculos vasto lateral (VL) e sóleo (S). Para os EJ e FP, respectivamente, o treinamento resultou em $29,9 \pm 4,4 \%$ e $21,6 \pm 5,4 \%$ de aumento na força dinâmica (1RM), 19,4 $\pm 4,3 \%$ e $12,4 \pm 4,7 \%$ no pico de torque isométrico e $24,1 \pm 6,3$ e $33,1 \pm 10,9 \%$ na potência articular máxima. Esses aumentos foram atribuídos, em grande parte, ao aumento significativo de $7,4 \pm 0,7 \%$ nos EJ e de $5,0 \pm 0,7 \%$ nos FP na ASTq por TC, enquanto nenhuma modificação foi observada em relação à integral da eletromiografia dos músculos VL e S. Esse estudo enfatizou o aumento na potência muscular mesmo através de um treinamento que usou baixa velocidade que pode ser capaz de manter um idoso apto a suportar, por exemplo, seu próprio peso em AVDs, mantendo-o independente e funcional.

Um dos primeiros trabalhos com TP em idosos foi realizado por EARLES et al. (2001). Nesse estudo 18 homens e mulheres (77 \pm 5 anos) participaram de um protocolo de TP para membros inferiores combinado com 45 minutos de caminhada em intensidade moderada. Esse grupo foi comparado com um grupo controle $(n=22)$, que somente realizava caminhada seis vezes por semana. O TP foi realizado três 
vezes por semana, durante 12 semanas, consistindo em três séries de dez repetições e intensidades que variaram entre 50 a $70 \%$ de 1RM. A maior parte do treino foi realizada em velocidade máxima. Foram avaliadas a força máxima, a potência (a $50 \%, 60 \%$ e $70 \%$ de 1RM) e o desempenho em alguns testes funcionais. Ambos os grupos tiveram melhoras na força máxima (22\% para o grupo que fez TP e $12 \%$ no grupo que apenas caminhou - efeito principal de tempo apenas). Porém, apenas o grupo que treinou potência apresentou um aumento significativo de $22 \%$ na potência no leg press. Mais especificamente, foi observado um aumento de $141 \%$ na potência a $70 \%$ de $1 \mathrm{RM}$. Adicionalmente, não foram observadas alterações no desempenho dos testes funcionais, resultado esse atribuído pelos autores ao excelente desempenho dos voluntários já antes do treinamento (11,8 segundos no teste de levantar e sentar da cadeira).

O estudo de FIELDING et al. (2002) é um dos pioneiros a comparar os efeitos dos TF e de TP. A amostra, composta por senhoras com média de idade de $73 \pm 1$ anos já apresentava algumas limitações funcionais, entre elas o uso de bengalas para caminhar e um ou mais déficits funcionais de acordo com uma escala de funcionalidade. A intervenção teve duração de 16 semanas, com frequência de três vezes por semana e, para ambos os grupos, intensidade de $70 \%$ de $1 \mathrm{RM}$, ajustadas a cada duas semanas, utilizando três séries de oito repetições. A diferença entre os grupos consistia na velocidade de execução dos movimentos nos exercícios de leg press bilateral e cadeira extensora unilateral. O grupo potência treinou na maior velocidade possível na fase concêntrica, tinha de manter a extensão total dos joelhos durante um segundo e realizava a fase excêntrica em dois segundos em ambos os exercícios. Já o grupo força, tinha que realizar essas fases em dois, um e dois segundos, respectivamente. A potência muscular foi medida em seis intensidades relativas à $1 \mathrm{RM}$, variando de 40 a 90\%. Já no início, o pico de potência foi relacionado significativamente com a velocidade habitual da marcha em ambos os grupos. Os autores observaram que o TP foi tão efetivo quanto o TF em relação ao aumento da força máxima (35\% para o grupo potência e $33 \%$ para o grupo força no leg press e $45 \%$ e $41 \%$ na cadeira extensora, respectivamente). Mas, o grupo que fez TP demonstrou um aumento significativamente maior no pico de potência no leg press $(141 \%$ x $42 \%$ para o TP e TF, respectivamente). Esse grupo já manifestava 
aumento de $53 \%$ no pico de potência após quatro semanas de treino, enquanto que o grupo que treinou força apresentou aumento de $25 \%$ só após oito semanas de treino. Para os autores, esses resultados sugerem mudanças no recrutamento e na ativação das UMs logo no princípio do treinamento, explicando assim, os ganhos de potência já no início do programa. Esse estudo segue a mesma tendência do estudo de EARLES et al. (2001) e BOTTARO et al. (2007) no qual os autores acreditam que o TP pode exercer maior influência benéfica nas alterações decorrentes do envelhecimento do que outros métodos de treinamento para idosos.

Baseados nas pesquisas vigentes a respeito dos efeitos do TP em idosos, MISZKO et al. (2003) questionaram se o TP poderia ser mais eficiente que o TF em relação ao aumento da performance funcional de idosos. Eles utilizaram uma amostra de 39 idosos, homens e mulheres (72 26,3 anos), inicialmente com baixo nível de potência (menos de $140 \mathrm{~W}$ para mulheres e menos de $210 \mathrm{~W}$ para homens na cadeira extensora), que foram distribuídos em três grupos: grupo força (GF), grupo potência (GP) e grupo controle (GC). Ambos os grupos experimentais treinaram durante 16 semanas, três vezes por semana. O GF realizava nove exercícios em intensidades que variaram entre 50 a $80 \%$ de uma repetição máxima (1RM), ajustadas a cada quatro semanas. Já o GP, fez o mesmo treino que o GF nas oito primeiras semanas e nas oito seguintes, manteve a intensidade de $40 \%$ de 1RM nos mesmos exercícios, porém realizando-os na maior velocidade possível na fase concêntrica. No GP, ao invés dos agachamentos foram realizados saltos verticais. Não houve diferenças nos ganhos de força e de potência anaeróbia (medida através do teste de Wingate em ciclo ergômetro) entre os grupos experimentais, o que, em parte, está de acordo com o estudo de FIELDING et al. (2002). Porém o GF tornouse significativamente mais forte no leg press e no supino e apresentou maior potência em relação ao GC, sem reportar as alterações em relação ao GP. Nos testes funcionais, o GP obteve score total significativamente maior que o GF. Por final, os autores concluem que o TP foi mais eficiente que o TF para o aumento da performance funcional em idosos com idade entre 65 e 90 anos, apesar de uma menor realização de trabalho total durante a intervenção. É importante salientar também que o GP realizou saltos verticais, uma tarefa complexa e com mais proximidade com a funcionalidade. Esse estudo é um dos primeiros a comparar 
diretamente as duas estratégias de treinamento e a transferência de suas adaptações para a funcionalidade. No entanto, devido à simplicidade em sua metodologia, o estudo não explica o porquê do resultado encontrado. Talvez se os autores avaliassem as adaptações neurais, por meio de EMG, pela observação do comportamento da curva força $x$ tempo, como foi realizado no estudo de HAKKINEN e HAKKINEN (1995), teríamos melhores explicações para a descoberta do estudo. No entanto, em relação a esses dois últimos estudos descritos (FIELDING et al., 2002; MISZKO et al., 2003) é importante ressaltar que, segundo CUOCO, CALLAHAN, SAYERS, FRONTERA, BEAN e FIELDING (2004), o grau de funcionalidade inicial dos sujeitos é de fundamental importância em relação à magnitude da resposta e em ambos os estudos os voluntários já apresentavam certo grau de deficiência funcional no início dos programas de treinamento.

$\mathrm{Na}$ mesma linha de raciocínio, mais recentemente, HENWOOD et al. (2008) também compararam os efeitos dos treinamentos de força e potência em idosos. No entanto, diferentemente dos estudos acima, a amostra foi composta por idosos independentes e, consequentemente, com boa performance funcional. Os dados foram obtidos de uma amostra de 53 idosos (65 a 84 anos) distribuídos em três grupos: grupo velocidade (GV), grupo força (GF) e grupo controle (GC) que treinaram duas vezes por semana, durante 24 semanas. O GF treinou a uma intensidade de $75 \%$ de $1 \mathrm{RM}$, com três séries de oito repetições e o GV realizou um treino misto com três séries de oito repetições, porém com intensidades diferentes (45\%, 60\% e 75\% de 1RM), com a maior velocidade possível na fase concêntrica. Os grupos realizaram seis exercícios (chest press, remada, flexão do cotovelo, leg press, cadeira flexora e cadeira extensora). Os resultados desse estudo não diferem muito dos obtidos nos estudos anteriores. A força dinâmica (1RM) aumentou similarmente nos grupos experimentais e não mudou no GC $(51,0 \pm 9,0 \%, 48,3 \pm 6,8 \%$ e $1,2 \pm 5,1 \%$ para GV, GF e GC, respectivamente). O mesmo comportamento foi visto na força isométrica $(29,7 \pm 6,9 \%, 23,8 \pm 5,5 \%$ e $1,5 \pm 4,1 \%$ para GV, GF e GC, respectivamente). Em relação à potência pico, os aumentos foram $50,5 \pm 4,1 \%, 33,8 \pm 3,8 \%$ e $-2,5 \pm 3,9 \%$ para GV, GF e GC, respectivamente. Durante o programa apenas a velocidade máxima de movimento no chest press apresentou uma significante diferença entre grupos, com o GF apresentando menor velocidade que o GV e o GC. E, finalmente em relação à 
performance em testes funcionais, não foram encontradas diferenças significativas entre os grupos experimentais. Em relação aos outros, esse estudo traz uma novidade quanto à característica da amostra estudada: idosos independentes. Parece que, de acordo com CUOCO et al. (2004), indivíduos já dotados de boa funcionalidade apresentam maior dificuldade em aumentar ainda mais a performance funcional. É importante ressaltar que nesse estudo o treino realizado pelo GV continha uma série com intensidade de $75 \%$ de $1 \mathrm{RM}$, o que diminui a velocidade de execução e, a média de intensidade ficou por volta de $60 \%$ de 1RM. Essas intensidades, quando comparadas às intensidades dos outros estudos, em relação ao TP é mais alta e talvez, por isso, se aproxime do TF, minimizando a diferenças dos programas (exceção feita para o estudo de FIELDING et al. (2002), que empregou $70 \%$ de $1 \mathrm{RM}$ em ambos os grupos, no entanto a amostra era composta por idosas com deficiência funcional pré estabelecida).

Como se observa, na literatura ainda não é clara a contribuição de cada tipo de treinamento (força e potência) no combate às alterações decorrentes do envelhecimento. Nota-se que, apesar de compararem os treinamentos, os estudos abordam apenas algumas das adaptações que ocorrem durante os dois tipos de intervenção. Ainda faltam na literatura mais estudos que abranjam as adaptações neurais, morfológicas e funcionais de uma única vez para que possamos elucidar a questão em torno da contribuição dos treinamentos de força e potência tanto em idosos frágeis como em idosos independentes.

\section{MATERIAIS E MÉTODOS}

\subsection{Amostra}

A amostra foi composta através de três recrutamentos realizados ao longo de um ano. Foram enviados e-mails, distribuídos folhetos nas ruas e realizadas algumas chamadas via rádio, todos direcionados a pessoas com idade entre 60 e 80 anos. Cento e trinta e três voluntários atenderam aos recrutamentos. Desses, 59 preencheram os critérios de inclusão estabelecidos para o estudo: serem sedentários ou praticantes de atividades aeróbicas esporadicamente, limitando-se a duas vezes por semana, não podiam apresentar demência, depressão, doença articular, 
osteoporose, hipertensão arterial ou qualquer alteração detectada no teste ergoespirométrico máximo sugestiva de problemas cardíacos. Assim, foram selecionados 59 voluntários que leram e assinaram o termo de consentimento. Os voluntários de cada grupo de recrutamento foram classificados em quartis de acordo com os valores de 1RM no exercício leg press e a área de secção transversa do músculo quadríceps femural da coxa direita. Após, os indivíduos de cada quartil foram aleatoriamente divididos entre os grupos força, potência e controle. Caso os indivíduos estivessem em quartis diferentes para as variáveis-critério (i.e. $1 \mathrm{RM}$ no leg press e ASTq), os mesmos foram agrupados de acordo com as combinações de quartis e, então divididos entre os grupos. Cada vez que os sujeitos foram alocados aos grupos, uma ANOVA one-way foi realizada para as duas variáveis-critério para verificar a ausência de diferenças entre os grupos. As análises não demonstraram diferenças entre os grupos $(p<0,05)$. O estudo foi concluído por 43 voluntários. As desistências foram provocadas por falta de adaptação ao dinamômetro isocinético (1), recusa para avaliação pós do grupo controle (6), motivos pessoais (5) e motivos de saúde não relacionados ao treino (4). O controle dos riscos cardiovasculares foi feito através dos critérios de seleção dos voluntários, descritos acima.

\subsection{Desenho do estudo}

De acordo com os recrutamentos, foram formados três sub-grupos ambos com os dois grupos experimentais (força e potência) e o grupo controle. Nas primeiras três semanas após o recrutamento, os candidatos a voluntários foram submetidos a entrevistas a respeito do seu estado de saúde, nível de atividade física, disponibilidade de tempo, responderam a questionários sobre esses mesmos quesitos, fizeram duas medidas da pressão arterial (PA), segundo a $V$ Diretrizes Brasileiras de Hipertensão Arterial (2006) (MION, KOHLMANN, MACHADO, AMODEO, GOMES, PRAXEDES, NOBRE, BRANDÃO, ZANELLA \& GUSMÃO, 2006), tiveram peso e altura aferidos e passaram em consulta clínica com um médico. Se após essas etapas o candidato fosse considerado apto pelo médico, um teste ergoespirométrico era realizado e, a ausência de alterações cardiovasculares nesse exame qualificava o voluntário para o estudo. Ao final dessa semana foi 
realizada uma bateria de testes funcionais, que será detalhada na seção 4.3.3. Na quarta semana, os voluntários foram submetidos a três sessões de familiarização aos testes no dinamômetro isocinético (aproximadamente trinta minutos) que também serviram para obtenção do posicionamento do voluntário no equipamento e a três sessões para aprender a executar os movimentos no leg press e no chest press (duas séries de dez repetições em dois dias e um teste de 3RM no terceiro dia). Na quinta semana foram realizados os testes de CVIM e de contração voluntária isométrica balística máxima (CVIBM), concomitantemente às medidas da ativação neural, por meio de EMG de superfície e, na sequência, os voluntários fizeram os testes de 1RM no chest press e depois no leg press. Ao término dessa semana foi realizada a medida da área de secção transversa do quadríceps (ASTq), com pelo menos 48 horas de intervalo entre as avaliações, através de ressonância nuclear magnética (RNM) e, com todos os resultados em mãos, foi feita randomização. Os voluntários foram classificados em quartis quanto à força máxima no teste de 1RM no leg press e quanto à ASTq. Após a classificação por quartis, os indivíduos dentro de cada um deles foram aleatoriamente divididos em três grupos (força, potência e controle). $\mathrm{O}$ treinamento aconteceu entre a sexta e a vigésima primeira semana do programa, com avaliações de 1RM a cada quatro semanas (oito sessões). Nas últimas três semanas foram realizados os pós testes (QUADRO 1). 
QUADRO 1 - Desenho do estudo.

\begin{tabular}{|l|l|l|l|l|}
\hline \multicolumn{1}{|c|}{$\begin{array}{c}\text { FASE DE } \\
\text { RECRUTAMENTO }\end{array}$} & $\begin{array}{c}\text { FASE DE } \\
\text { FAMILIARIZAÇÃO }\end{array}$ & $\begin{array}{l}\text { FASE DE PRÉ } \\
\text { TESTES }\end{array}$ & $\begin{array}{c}\text { FASE DE } \\
\text { TREINAMENTO }\end{array}$ & $\begin{array}{l}\text { FASE DE PÓS } \\
\text { TESTES }\end{array}$ \\
\hline $\begin{array}{l}\text { Entrevista e } \\
\text { questionários; }\end{array}$ & $\begin{array}{l}\text { Familiarização ao } \\
\text { dinamômetro; }\end{array}$ & CVIM + EMG; & $\begin{array}{l}\text { Treino } \\
(2 \times / \text { semana); }\end{array}$ & $\begin{array}{l}\text { CVIM + EMG } \\
\text { pós; }\end{array}$ \\
\hline Medidas de PA; & $\begin{array}{l}\text { Familiarização no } \\
\text { leg press e no } \\
\text { supino; }\end{array}$ & CVIMB + EMG; & 32 sessões; & $\begin{array}{l}\text { CVIMB + EMG } \\
\text { pós; }\end{array}$ \\
\hline Consulta Médica; & Teste de 3RM. & $\begin{array}{l}\text { 1 RM no leg } \\
\text { press e no } \\
\text { supino; }\end{array}$ & $\begin{array}{l}\text { Avaliações de } \\
\text { 1RM periódicas. }\end{array}$ & $\begin{array}{l}\text { 1 RM no leg } \\
\text { press e no } \\
\text { supino pós; }\end{array}$ \\
\hline $\begin{array}{l}\text { Teste } \\
\text { Ergoespirométrico; }\end{array}$ & ASTq; & $\begin{array}{l}\text { Testes } \\
\text { Funcionais pós; }\end{array}$ \\
\hline Testes Funcionais. & Randomização. & AST pós. \\
\hline
\end{tabular}

Legenda: PA: pressão arterial; CVIM: contração voluntária isométrica máxima; CVIBM: contração voluntária isométrica balística máxima; EMG: eletromiografia; ASTq: área de secção transversa do quadríceps por meio de ressonância nuclear magnética.

\subsection{Avaliações e testes}

\subsubsection{Avaliações}

Foram realizadas as avaliações de demência através do Mini Exame do Estado Mental MEEM (Mini Mental State Examination) (FOLSTEIN, FOLSTEIN \& MCHUGH, 1975; BERTOLUCCI, BRUCKI, CAMPACCI \& JULIANO, 1994) para evitar a inclusão de idosos demenciados, o que dificultaria o aprendizado das tarefas e a percepção de trabalho realizado (ANEXO II); avaliação de depressão através de questionário que avalia sintomas depressivos (HOTATIAN, 2002), para evitar a inclusão de idosos deprimidos, o que diminuiria a motivação e adesão dos sujeitos ao programa (ANEXO III) e a avaliação médica na qual, além do exame clínico (peso, altura, eletrocardiograma de repouso, checagem de exames anteriores das principais articulações e de desintometria óssea) era realizada uma anamnese que auxiliava o médico na avaliação desse participante (ANEXO IV). 


\subsubsection{Teste ergoespirométrico máximo}

Esse teste foi realizado em uma esteira rolante (Inbrasport, modelo ATL, Porto Alegre, Brasil), utilizando-se um protocolo em rampa programado para que o indivíduo atingisse a exaustão em $10 \pm 2$ minutos. No momento do teste, um médico e um professor de Educação Física estavam ao lado do voluntário monitorando-o e encorajando-o. Durante o teste, a frequência cardíaca foi constantemente monitorada através de eletocardiógrafo de registro simultâneo das 12 derivações padrão (Cardio Perfect, MD - Delft, Holanda) e registrada ao final de cada dois minutos. A pressão arterial foi medida a cada dois minutos pelo método auscultatório, por meio de um esfigmomanômetro de coluna de mercúrio. A análise do sinal eletrocardiográfico foi realizada através da observação atenta e contínua do sinal de eletrocardiograma digital, com especial atenção às alterações do segmento ST e da onda T, distúrbios do ritmo e da condução intraventricular e foram registradas no laudo as anormalidades encontradas durante o teste. Os critérios adotados para a interrupção dos testes foram: cansaço físico intenso ou problemas de saúde que impedissem a continuidade do teste, como, por exemplo, pressão arterial sistólica maior que 260 $\mathrm{mmHg}$ e/ou diastólica maior que $120 \mathrm{mmHg}$ e/ou alterações eletrocardiográficas relacionadas a doenças cardiovasculares, seguindo-se as recomendações das II Diretrizes da Sociedade Brasileira de Cardiologia Sobre Teste Ergométrico.

\subsubsection{Bateria de testes funcionais}

Os idosos foram submetidos aos seguintes testes funcionais:

- Flexibilidade - sentar e alcançar - (SA): O voluntário sentava na borda de uma cadeira com $43 \mathrm{~cm}$ de altura, com um joelho flexionado $\left(90^{\circ}\right)$, o outro estendido o máximo possível e tornozelo em posição neutra $\left(90^{\circ}\right)$. A partir dessa posição, descia lentamente o tronco com os braços estendidos e as mãos sobrepostas na tentativa de alcançar o hálux. A extremidade do hálux correspondia ao ponto zero. Não alcançando esse ponto, o resultado foi classificado como negativo (distância que faltar até o hálux) e, ultrapassandoo, o resultado foi positivo (distância alcançada depois do hálux). Foram realizadas duas tentativas prévias para a escolha do membro que o voluntário 
percebesse maior facilidade (maior distância alcançada). Uma vez escolhido o membro, duas tentativas foram realizadas e o melhor escore entre elas foi utilizado (RIKLI \& JONES, 1999).

- Equilíbrio e Agilidade - Levantar a partir da posição no chão - (LD e L6): Esse teste foi composto por duas etapas. Para cada etapa o voluntário teve uma tentativa para familiarizar-se ao teste. Na primeira (LD), o voluntário iniciava o teste em decúbito dorsal no chão (cotovelos e joelhos estendidos). A tarefa consistia em levantar-se o mais rápido possível e ficar de pé sem o auxílio de nenhum suporte. Eles tiveram duas tentativas para executar essa tarefa. $\mathrm{Na}$ segunda etapa (L6), o voluntário começava o teste a partir da posição de seis apoios (ante-pés, joelhos e mãos) e, da mesma forma que a anterior, tinha de ficar de pé, sem a utilização de nenhum outro suporte (também tiveram duas tentativas). Foram anotados os tempos (em segundos) de realização das tarefas nas duas tentativas e o melhor escore de cada uma (menor tempo) foi utilizado na análise estatística (ALEXANDER et al., 1997).

- Equilíbrio - Ficar em apoio simples (AS): O voluntário tinha de permanecer em apoio simples, sem nenhum tipo de suporte, por pelo menos cinco segundos. Antes do teste propriamente dito, o voluntário pôde fazer duas tentativas para escolher o membro mais estável para realização do teste. Uma vez escolhido, o voluntário se posicionava e dizia "Estou pronto". A partir desse comando o avaliador disparava o cronômetro. A tarefa só foi considerada cumprida após o voluntário ter permanecido cinco segundos em apoio simples, qualquer tempo menor que esse determinava o não cumprimento da tarefa (VELLAS et al., 1997).

- Agilidade - levantar, ir e voltar - (LIV): O voluntário iniciava o teste sentado em uma cadeira de $43 \mathrm{~cm}$ de altura, com os braços estendidos e pés totalmente apoiados no solo. Ao sinal do avaliador, o voluntário levantava-se sem o auxílio das mãos e caminhava o mais rápido possível, sem correr, contornava um cone posicionado a uma distância de três metros da cadeira e 
retornava à posição inicial. O cronômetro foi acionado a partir do sinal do avaliador e, novamente quando o voluntário se sentava totalmente na cadeira. Após demonstração, o voluntário fazia uma tentativa do teste para familiarizarse e após um minuto, foram realizadas duas tentativas, com um minuto de intervalo entre elas. O melhor escore (menor tempo em segundos) foi usado para a análise estatística (SHUMWAY-COOK et al., 2000).

- Força de membros inferiores (FMI): O voluntário iniciava o teste sentado em uma cadeira de $43 \mathrm{~cm}$ de altura, com as costas apoiadas, os braços cruzados à frente do peito (mantendo-os assim até o final) e os pés bem apoiados no chão. Ao sinal do avaliador, o voluntário tinha de levantar e sentar na cadeira cinco vezes o mais rápido possível, sem tirar os pés do chão e estendendo totalmente os joelhos e o tronco. O cronômetro foi acionado no momento em que o examinador desse o comando de 'VAl' e parado assim que o voluntário sentava à cadeira na quinta repetição. Cada repetição correspondeu a cada vez que o voluntário transferia todo seu peso para a cadeira (WHITNEY et al., 2005).

- Velocidade da Marcha - (VMAR): O sujeito descansava, no mínimo, três minutos do teste anterior para esse. O voluntário teve que percorrer uma distância de 30 metros em duas tentativas (com dois minutos de intervalo entre elas), na maior velocidade possível, sem correr, sem o uso de acessórios (muletas, bengalas, etc.). A velocidade média da marcha foi calculada através da divisão da distância pelo menor tempo gasto para percorrer o percurso total.

- Teste de seis minutos de caminhada - (6MC): O voluntário caminhava o mais rápido que puder, sem correr, durante seis minutos em volta de um circuito de cones posicionados a cada 4,57 metros, de maneira a formar um grande retângulo. Caso o voluntário sentisse necessidade, podia parar para descansar, ou até mesmo, interromper o teste. Foi considerada a distância 
percorrida durante este tempo ou até onde o voluntário conseguiu chegar (ENRIGHT, 2003).

\subsubsection{Teste de força dinâmica máxima}

A força dinâmica foi medida através do teste de 1RM (uma repetição máxima), que é a quantidade de peso que pode ser movida uma única vez durante toda a amplitude de movimento e de maneira adequada (HENWOOD et al., 2008). Foram respeitados os critérios estabelecidos por BROWN e WHEIR (2001). Esse teste foi realizado nos exercícios de chest press e leg press (Technogyn, Ganbettola Itália), para avaliar a força dinâmica máxima de membros superiores e inferiores, respectivamente. Esses exercícios multi-articulares exigem uma resposta neural mais complexa e tem sido considerados mais efetivos no aumento da força muscular global, uma vez que através deles, uma maior quantidade de peso pode ser utilizada (RATAMESS, ALVAR, EVETOCH, HOUSH, KIBLER, KRAEMER \& TRIPLETT, 2009). O voluntário fez um aquecimento geral prévio, em esteira rolante durante dez minutos a uma velocidade de $5 \mathrm{~km} / \mathrm{h}$. Duas séries de aquecimento específico foram realizadas antes do início do teste propriamente dito. A primeira consistiu de cinco repetições a $50 \%$ da carga máxima prevista (chest press $\pm 80 \%$ do peso corporal e leg press \pm 2 vezes o peso corporal) e a segunda, com $70 \%$ desse valor. Entre elas houve um intervalo de dois minutos. Após o aquecimento específico os avaliadores tiveram até cinco tentativas para encontrar a RM do voluntário, com no mínimo, três minutos de intervalo entre elas. As regulagens foram feitas de maneira que, ao apoiarem os pés na plataforma do leg press os voluntários formassem um ângulo de $90^{\circ}$ com os joelhos em relação ao quadril, garantindo que as costas e cabeça estivessem totalmente apoiadas e, o mesmo foi feito no chest press, utilizando um step e a regulagem do banco para deixar os joelhos em $90^{\circ}$ em relação ao chão. Essas medidas foram anotadas para serem utilizadas nos testes futuros, garantindo a reprodutibilidade dos mesmos. Anteriormente a esse teste propriamente dito, foram realizadas duas sessões de familiarização, uma na qual os sujeitos realizaram duas séries de 10 repetições com carga leve para aprender o movimento (na qual as regulagens foram feitas e anotadas) e outra, $48 \mathrm{~h}$ depois, de familiarização ao teste 
de força máxima, porém consistia de 3RM, para adquirirmos uma idéia do valor aproximado para predição do teste de 1RM, que foi realizado com intervalo de pelo menos $48 \mathrm{~h}$ em relação ao teste de 3RM.

\subsubsection{Testes de força isométrica máxima}

- Contração Voluntária Isométrica Máxima (CVIM) de membros inferiores

O voluntário permaneceu sentado em uma cadeira extensora que fazia parte do dinamômetro isocinético da marca Biodex System 3 (Biomedical Systems, Newark, CA, USA). Seu tronco e quadril foram presos por cintos para evitar movimentos acessórios. O centro de rotação do joelho (linha intercondilar média) da perna direita foi alinhado com o centro de rotação do braço do aparelho, que foi fixado em um ângulo de $60^{\circ}$ em relação à horizontal. O ponto de apoio do braço de alavanca do aparelho foi situado a um centímetro proximal do maléolo medial do sujeito. O torque líquido produzido na articulação do joelho foi obtido diretamente através do programa acoplado ao sistema do dinamômetro. A freqüência de aquisição dos dados de força foi de $500 \mathrm{~Hz}$. Os voluntários fizeram duas tentativas, com três minutos de intervalo entre elas e foram instruídos a atingir o nível de força máxima em dois segundos e manter essa força por mais dois segundos. Nessa tarefa foram avaliados o pico de torque em rampa e a ativação neural (RMS).

- Contração Voluntária Isométrica Máxima Balística (CVIBM) de membros inferiores

Os procedimentos para esse teste foram os mesmos descritos anteriormente, porém os sujeitos foram instruídos a atingir o pico de força o mais rápido possível e mantê-lo por dois segundos. Nessa tarefa foram avaliados o pico de torque balístico, a taxa de desenvolvimento de força (TDF), o retardo eletromecâncio (REM) e também a ativação neural (RMS). Ambos os testes foram precedidos de três sessões de familiarização separadas por pelo menos $48 \mathrm{~h}$, para regulagem do aparelho e aprendizagem da tarefa, com o intuito de minimizar os efeitos da mesma. 


\subsubsection{Ativação neural, retardo eletromecânico e taxa de desenvolvimento de força}

\section{- Ativação neural - RMS}

Durante a realização da CVIM e da CVIBM foi realizada concomitantemente a avaliação da ativação neural através da eletromiografia de superfície. A pele do sujeito foi devidamente preparada (tricotomia, esfoliação, limpeza com álcool isopropílico para diminuir a impedância para valores menores que $150 \Omega$ e aplicação de gel condutor) para a colocação de dois pares de eletrodos bipolares de superfície, com distância intereletrodos de $2 \mathrm{~cm}$. Os eletrodos $(2 \times 2 \mathrm{~cm})$ foram colocados no maior volume muscular seguindo a provável orientação das fibras de ambos os músculos vasto medial $(\mathrm{VM})$ e vasto lateral $(\mathrm{VL})$. Estes captaram os sinais elétricos dos músculos durante $500 \mathrm{~ms}$ antes e após o pico de torque. O sinal foi capturado por uma unidade de EMG (Miosystem, Miosystem., Brasil) e analisado através de sua raiz quadrada média (RMS) segundo a equação $1 \mathrm{em}$ um software customizado. Os dados foram salvos em um computador HP Pavillion dv6000, processador AMD Turion64 X2. A freqüência de aquisição de sinal eletromiográfico foi de $1000 \mathrm{~Hz}$, com filtros de passa banda com freqüências de corte de 20 e $500 \mathrm{~Hz}$ RICARD et al. (2005). Para garantir a mesma colocação dos eletrodos pré e pós teste, uma transparência foi utilizada para registro da posição dos eletrodos assim como para a identificação de sinais anatômicos tais como pintas e cicatrizes.

Equação 1:

$$
x_{\mathrm{rms}}=\sqrt{\frac{1}{n} \sum_{i=1}^{n} x_{i}^{2}}=\sqrt{\frac{x_{1}^{2}+x_{2}^{2}+\cdots+x_{n}^{2}}{n}} .
$$

onde: $\mathrm{x}=$ cada um dos sinais obtidos em cada milissegundo de coleta, $\mathrm{n}=$ número de sinais coletados. 
- $\quad$ Retardo eletro-mecânico (REM)

Para análise do REM foram utilizados as tentativas na CVIBM e o mesmo software customizado utilizado para análise da ativação neural. O REM foi calculado de duas maneiras distintas descritas abaixo.

a) O REM foi calculado baseado na diferença de tempo entre o início da atividade elétrica dos músculos VM e VL e o início da produção de torque (REEVES, MAGANARIS \& NARICI, 2003a). Para determinar o início da atividade elétrica e do torque, inicialmente foram calculados a média e o desvio padrão em um trecho no qual o sinal fosse estável. Essa estabilidade foi determinada por análise visual. Após isso, foi determinado quando os valores de RMS e torque superassem em dois desvios padrão as médias calculadas previamente. O REM foi calculado subtraindo do tempo de início do torque o tempo de início da atividade eletromiográfica;

b) O REM também foi calculado através do método de cross-correlation (correlação cruzada). Através desse método estimamos o grau de correlação entre os sinais de atividade eletromiográfica e de torque manipulando temporalmente (300 milissegundos para frente e para traz) em cada uma das curvas geradas por cada sinal. Assim, o ponto que gerava a maior correlação entre os sinais era considerado então o REM.

- $\quad$ Taxa de desenvolvimento de força (TDF)

Assim como o REM, a TDF foi coletada durante a CVIBM e analisada com o mesmo software customizado. Essa medida nos forneceu a maior velocidade em que o torque foi gerado durante momentos pré determinados da contração: nos primeiros 100 milissegundos (TDF100), pela seleção do intervalo de $50 \mathrm{~ms}$, até o pico, com maior TDF nos movendo no tempo a cada segundo (TDF máx), e nos momentos em que o torque era de $25 \%, 50 \%$ e $75 \%$ da CVBIM. Também foi calculado o tempo, após o início da contração, onde ocorreu o maior valor da TDF (tTDF), analisado a cada 50 milissegundos (RICARD et al., 2005). 


\subsection{7 Área de secção transversa do quadríceps}

A ASTq foi obtida através de exame de Ressonância Nuclear Magnética (RNM) (Signa LX 9.1, GE Healthcare, Milwaukee, USA). O voluntário foi acompanhado até o aparelho de ressonância por um técnico de imagem onde permaneceu deitado, em decúbito ventral dentro do aparelho, com os joelhos estendidos. Durante o exame os voluntários foram instruídos a relaxar sua musculatura o máximo possível. Pequenos sacos de areia foram colocados na região dos tornozelos, apoiando-os, para impedir o movimento dos pés e pernas durante 0 exame e garantir a posição relaxada. As imagens foram capturadas de ambas as pernas. Uma medida inicial foi feita para determinar a distância perpendicular do tracânter maior do fêmur até a borda inferior do epicôndilo lateral desse mesmo osso. Essa medida determinou o tamanho do segmento. A seqüência de pulso foi realizada com um campo de visão entre 400 e 420 mm, o tempo de cada repetição foi de 350 milissegundos, o tempo de eco, de nove a 11 milissegundos, foram dois sinais de aquisição e a matriz de reconstrução de 256 × 256. Foram feitas nove imagens, com cortes de $0,8 \mathrm{~cm}$ a cada três segundos, sendo que de cada região do segmento (proximal, medial e distal) foram feitas três imagens. A AST adotada para a análise estatística foi a da região medial, através do corte medial. As imagens foram transferidas para uma estação de tratamento (Advantage Workstation 4.3, GE Healthcare, Milwaukee, USA) para determinação da ASTq. No corte do segmento era possível visualizar músculo esquelético, gordura subcutânea, osso e tecido residual. Assim, a ASTq foi determinada através do contorno da área que continha apenas músculo esquelético, subtraindo do corte total as áreas ocupadas por osso e gordura subcutânea.

\subsubsection{Tensão específica}

Essa medida foi obtida através da razão entre o torque isométrico líquido máximo dos extensores do joelho e a área de secção transversa do músculo quadríceps femural. 


\subsection{Protocolos de treinamento}

O período de treinamento foi de 16 (dezesseis) semanas. Os voluntários foram distribuídos, randomicamente, em três grupos. O grupo Força (GF) e o grupo Potência (GP) foram submetidos aos protocolos de treinamento descritos abaixo, enquanto que o grupo Controle (GC) não foi submetido a nenhum protocolo de treinamento.

Antes do início do treino, todos os voluntários dos grupos experimentais realizavam um aquecimento geral durante dez minutos em esteira ergométrica (Life Fitness $($ ), a uma velocidade de $5 \mathrm{~km} / \mathrm{h}$. Os grupos experimentais realizaram sete exercícios: leg press, cadeira flexora, extensão do quadril, flexão plantar, chest press, remada anterior, remada alta. Todos os exercícios foram realizados em máquinas da marca Technogym $®$, linha Selection, Itália. Os intervalos entre séries e entre exercícios foram sempre de, no mínimo, três minutos para garantir a total recuperação dos voluntários. Além desses exercícios, também foram realizados dois exercícios estabilizadores sobre fitball, com o intuito de fortalecer a região abdominal e lombar. Os treinos ocorreram duas vezes por semana, às terças e quintas feiras no período da manhã. A cada quatro semanas os voluntários foram avaliados em relação à força dinâmica máxima nos exercícios de leg press e chest press e tiveram suas cargas de treinamento reajustadas conforme o novo valor de $1 \mathrm{RM}$ e a intensidade, de acordo com a periodização.

\subsubsection{Treinamento de força}

Esse tipo de intervenção teve intensidade que variou entre $70 \%$ a $90 \%$ de $1 \mathrm{RM}$ obtidos nos exercícios de leg press e chest press. Para os outros exercícios a intensidade foi a mesma, porém foi determinada pela percepção de esforço de cada voluntário, sempre tendo como referências os exercícios nos quais eles foram avaliados e de acordo com a observação dos professores. Ou seja, para membros inferiores eles tiveram como referência o leg press e para membros superiores, o chest press. Os voluntários fizeram testes de 1RM a cada quatro semanas e estas foram consideradas como sessão de treino dentro das 32 sessões programadas. 
Para garantirmos uma intensidade média em torno dos $80 \%$, característica desse tipo de treinamento, foi seguida a periodização que consta na TABELA 1, cujos detalhes seguem abaixo:

TABELA 1: Periodização do treinamento de força ao longo de 16 semanas.

\begin{tabular}{|c|c|}
\hline Período & Séries/Repetições \\
\hline Semanas 1 e 2 & $2^{10}(70 \%)$ \\
\hline Semanas 3 e 4 & $2^{10}(75 \%)$ \\
\hline Semanas 5 a 8 & $2^{10}(75 \%) ; 1^{8}(80 \%)$ \\
\hline Semanas 9 a 12 & $3^{8}(80 \%)$ \\
\hline Semanas 13 e 14 & $2^{8}(80 \%) ; 2^{6}(85 \%)$ \\
\hline Semanas 15 e 16 & $4^{4}(90 \%)$ \\
\hline
\end{tabular}

12: a base representa o número de séries e o expoente, o número de repetições. Entre parênteses, a intensidade do exercício.

Semanas 1 e 2: foram realizadas duas séries de dez repetições, com intensidade média de $70 \%$ de $1 \mathrm{RM}$. O exercício na bola foi a flexão do quadril unilateral, com duas séries de 10 repetições;

Semanas 3 e 4: foram realizadas duas séries de dez repetições, com intensidade média de $75 \%$ de 1 RM. O exercício na bola foi a flexão do quadril unilateral, com duas séries de 10 repetições;

Semanas 5 a 8: foram realizadas duas séries de dez repetições com intensidade de $75 \%$ de $1 \mathrm{RM}$ e uma série de oito repetições com intensidade média de $80 \%$ de 1RM. O exercício na bola foi a flexão do quadril unilateral, com três séries de 10 repetições;

Semanas 9 a 12: foram realizadas três séries de dez repetições com intensidade de $80 \%$ de 1RM. O exercício na bola foi a extensão do tronco, com duas séries de 10 repetições;

Semanas 13 e 14: foram realizadas duas séries de oito repetições com intensidade de $80 \%$ de 1 RM e duas séries de seis repetições com intensidade de $85 \%$ de 1RM. O exercício na bola foi a extensão do tronco, com duas séries de 10 repetições. 
Semanas 15 e 16: foram realizadas duas séries de seis repetições com intensidade de $85 \%$ de $1 \mathrm{RM}$ e duas séries de quatro repetições com intensidade de $90 \%$ de 1RM. O exercício na bola foi a extensão do tronco, com duas séries de 10 repetições.

\subsubsection{Treinamento de potência}

Os voluntários do GP foram submetidos a intensidades que variaram de $30 \%$ a $50 \%$ de 1 RM obtidos no leg press e no chest press. Assim como no GF, a intensidade dos outros exercícios foi baseada na percepção de esforço dos exercícios nos quais eles foram avaliados e por meio da percepção e experiência dos professores. Os sujeitos foram constantemente instruídos a realizarem os exercícios na maior velocidade possível na fase concêntrica e controlar a fase excêntrica. Com o intuito de submetê-los a um programa com intensidade média por volta dos $40 \%$, própria do TP, a periodização desse grupo, resumida na TABELA 2, foi a seguinte:

TABELA 2: Periodização do treinamento de potência ao longo de 16 semanas.

\begin{tabular}{|c|c|}
\hline Período & Séries/Repetições \\
\hline Semanas 1 e 2 & $3^{7}(30 \%)$ \\
\hline Semanas 3 e 4 & $3^{7}(35 \%)$ \\
\hline Semanas 5 a 8 & $3^{7}(30 \%) ; 1^{6}(40 \%)$ \\
\hline Semanas 9 a 12 & $4^{6}(40 \%)$ \\
\hline Semanas 13 e 14 & $2^{6}(40 \%) ; 2^{4}(45 \%)$ \\
\hline Semanas 15 e 16 & $2^{6}(45 \%) ; 2^{4}(50 \%)$ \\
\hline
\end{tabular}

12: a base representa o número de séries e o expoente, o número de repetições. Entre parênteses, a intensidade do exercício.

Semanas 1 e 2: foram realizadas três séries de sete repetições, com intensidade média de $30 \%$ de 1RM. O exercício na bola seguiu mesma progressão do TF e foi o único onde a velocidade não era determinante.

Semanas 3 e 4: foram realizadas três séries de sete repetições, com intensidade média de $35 \%$ de 1RM; 
Semanas 5 a 8: foram realizadas três séries de sete repetições com intensidade de $35 \%$ de $1 \mathrm{RM}$ e uma série de seis repetições com intensidade média de $40 \%$ de $1 \mathrm{RM}$;

Semanas 9 a 12: foram realizadas quatro séries de seis repetições com intensidade de $40 \%$ de $1 \mathrm{RM}$;

Semanas 13 e 14: foram realizadas duas séries de seis repetições com intensidade de $40 \%$ de $1 \mathrm{RM}$ e duas séries de quatro repetições com intensidade de $45 \%$ de $1 \mathrm{RM}$;

Semanas 15 e 16: foram realizadas duas séries de seis repetições com intensidade de $45 \%$ de $1 \mathrm{RM}$ e duas séries de quatro repetições com intensidade média de $50 \%$ de $1 \mathrm{RM}$.

\subsection{Análise estatística}

Inicialmente os dados foram analisados visual e quantitativamente (AndersonDarling) quanto à normalidade e existência de outliers. Para as variáveis dependentes força dinâmica, pico de torque isométrico nas diferentes condições (CVIM e CVIBM), área de secção transversa do quadríceps, amplitude da atividade eletromiográfica (RMS), taxa de desenvolvimento de força (TDF) e retardo eletromecânico (REM) foi utilizado um modelo misto tendo grupo e tempo como fatores fixos e voluntários como fator aleatório. Em caso de valores de $\mathrm{F}$ significantes, post-hocs com ajustamento de Tukey foram utilizados para efeitos de comparações múltiplas. O nível de significância adotado foi de $p<0,05$. Os dados foram apresentados como médias e desvios padrão.

\section{RESULTADOS}

Inicialmente os três grupos eram semelhantes em termos de estatura, peso e idade (TABELA 3), não havendo diferenças significantes entre eles. A adesão ao estudo foi alta, uma vez que a maioria dos sujeitos realizou mais de $95 \%$ das 32 sessões de treino oferecidas. Após o período de seguimento dez voluntários $(77 \%)$ 
do GC participaram de um dos tipos de treinamento oferecido após terem realizado as avaliações.

TABELA 3 - Características iniciais da amostra nos grupos controle (GC), força (GF) e potência $(G P)$, média $( \pm D P)$.

\begin{tabular}{|c|c|c|c|c|}
\hline Grupo & Sujeitos & $\begin{array}{c}\text { Estatura } \\
\text { (cm) }\end{array}$ & $\begin{array}{c}\text { Peso } \\
(\mathbf{k g})\end{array}$ & $\begin{array}{c}\text { Idade } \\
(\text { anos) }\end{array}$ \\
\hline GC & $13(2 \mathrm{H} ; 11 \mathrm{M})$ & $159,8( \pm 6,8)$ & $67,2( \pm 10,8)$ & $63,0( \pm 4,0)$ \\
\hline GF & $14(5 \mathrm{H} ; 9 \mathrm{M})$ & $163,9( \pm 9,8)$ & $79,7( \pm 17,2)$ & $63,6( \pm 4,0)$ \\
\hline GP & $16(4 \mathrm{H} ; 12 \mathrm{M})$ & $157,4( \pm 7,7)$ & $63,9( \pm 11,9)$ & $64,9( \pm 3,9)$ \\
\hline Total & $43(11 \mathrm{H} ; 32 \mathrm{M})$ & $160,2( \pm 8,4)$ & $67,2( \pm 13,4)$ & $63,8( \pm 4,0)$ \\
\hline
\end{tabular}

$\mathrm{H}$ : homens; M: mulheres

\section{Teste ergoespirométrico máximo}

$\mathrm{O}$ valores de $\mathrm{VO}_{2 \text { máx }}$ aumentaram do pré- para o pós-teste (efeito principal de tempo, $p=0,0005$, GC: $23,0 \pm 3,8$ para $23,9 \pm 4,8$; GF: $21,7 \pm 5,1$ para $23,4 \pm 3,8$ e o GP: $22,9 \pm 4,3$ para $25,8 \pm 5,1 \mathrm{ml}$ de $\mathrm{O}_{2} \cdot \mathrm{kg}^{-1} \cdot \mathrm{min}^{-1}$, pré e pós intervenção, respectivamente, média $\pm \mathrm{DP}$ ).

\section{Força dinâmica máxima (1RM)}

Aumentos significantes na força dos membros inferiores, no exercício de leg press, foram observados no GF e GP $(42,7 \%$ e $33,8 \%$, respectivamente, $p<0,0001)$ e uma redução não significante (ns) de $6,7 \%$ no GC (FIGURA 1A). Não houve diferença entre GF e GP após a intervenção $(p=0,6373)$. Para os membros superiores, no exercício de chest press, diferenças significantes também foram observadas após o período de treinamento ( $\mathrm{p}<0,0001)$, com aumentos de $31 \%$ e 25,4\% para GF e GP, respectivamente, em relação à condição pré (FIGURA 1B). Porém, o aumento no GP não foi suficiente para diferi-lo do GC na condição pós $(p=0,46)$ e não houve diferença entre GF e GP após o treinamento $(p=0,5082)$. 
A

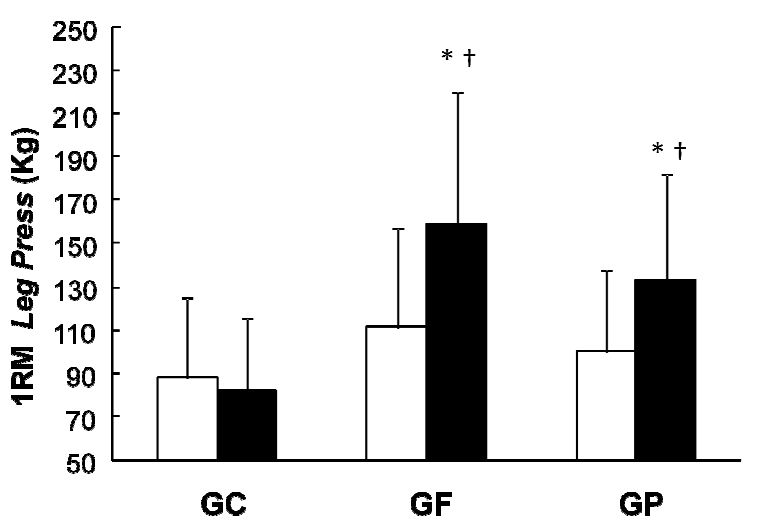

B

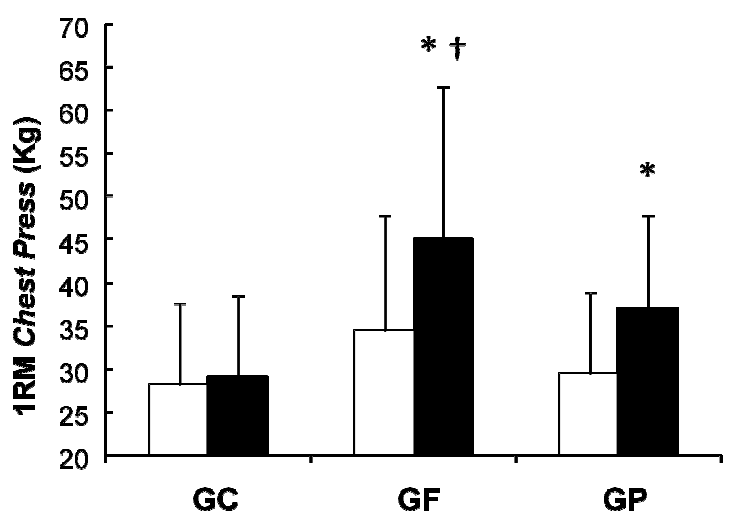

$\square$ PRÉ \ PÓS

* valores no pós treino maiores que valores no pré treino, $p<0,0001$; $†$ valores pós treino maiores que os do GC, $p<0,0429$.

FIGURA 1 - Força dinâmica máxima $(\mathrm{Kg})$ no leg press $(\mathrm{A})$ e no chest press (B) para os grupos controle (GC), força (GF) e potência (GP) pré e pós treino.

\section{Área de secção transversa do quadríceps}

Ambos os grupos experimentais apresentaram aumentos significantes na ASTq da região medial (FIGURA 2) do pré para o pós treino, porém os valores obtidos pós intervenção não foram diferentes dos valores pós do GC. Os aumentos foram da ordem de 2,8\% (ns; $p=0,2279), 6,5 \%(p<0,0001)$ e 3,4\% ( $p=0,0028)$ na coxa esquerda e 2,5\% (ns; $p=0,7988), 5,5 \%(p<0,0001)$ e $3,9 \%(p=0,0037)$ na coxa direita, para GC, GF e GP, respectivamente. 


\section{A}

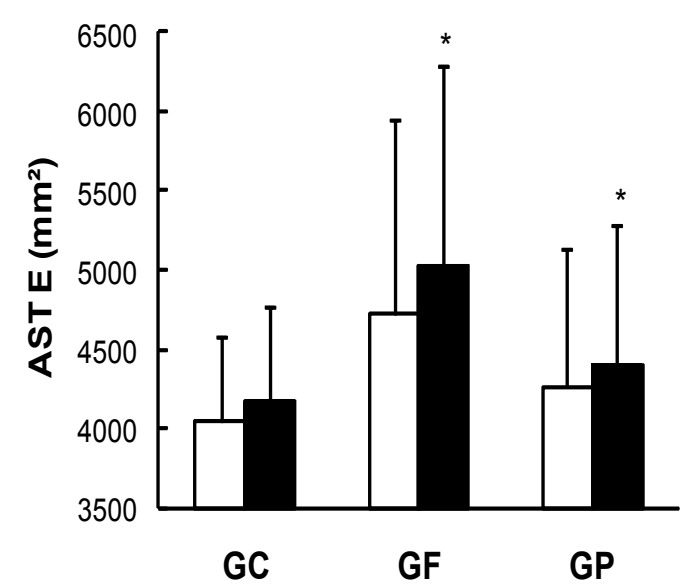

B

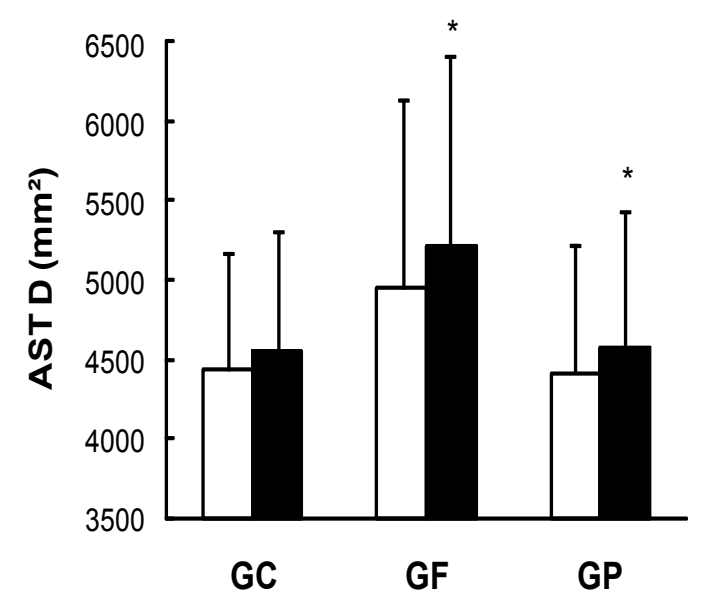

$\square$ PRÉ $\square$ PÓS

*: valores pós teste maiores que valores pré teste, $p<0,0037$.

FIGURA 2 - Área de secção transversa da região medial do músculo quadríceps femural (AST, $\mathrm{mm}^{2}$ ), da coxa esquerda (A) e da coxa direita (B) para os grupos controle (GC), força (GF) e potência (GP) pré e pós treino.

\section{Tensão específica}

Houve um efeito principal de tempo para a tensão específica $(p=0,0006)$, no qual o percentual de aumento para os grupos GC, GF e GP foram de $6,1 \%, 16,6 \%$ e $14,2 \%$, respectivamente (FIGURA 3). 


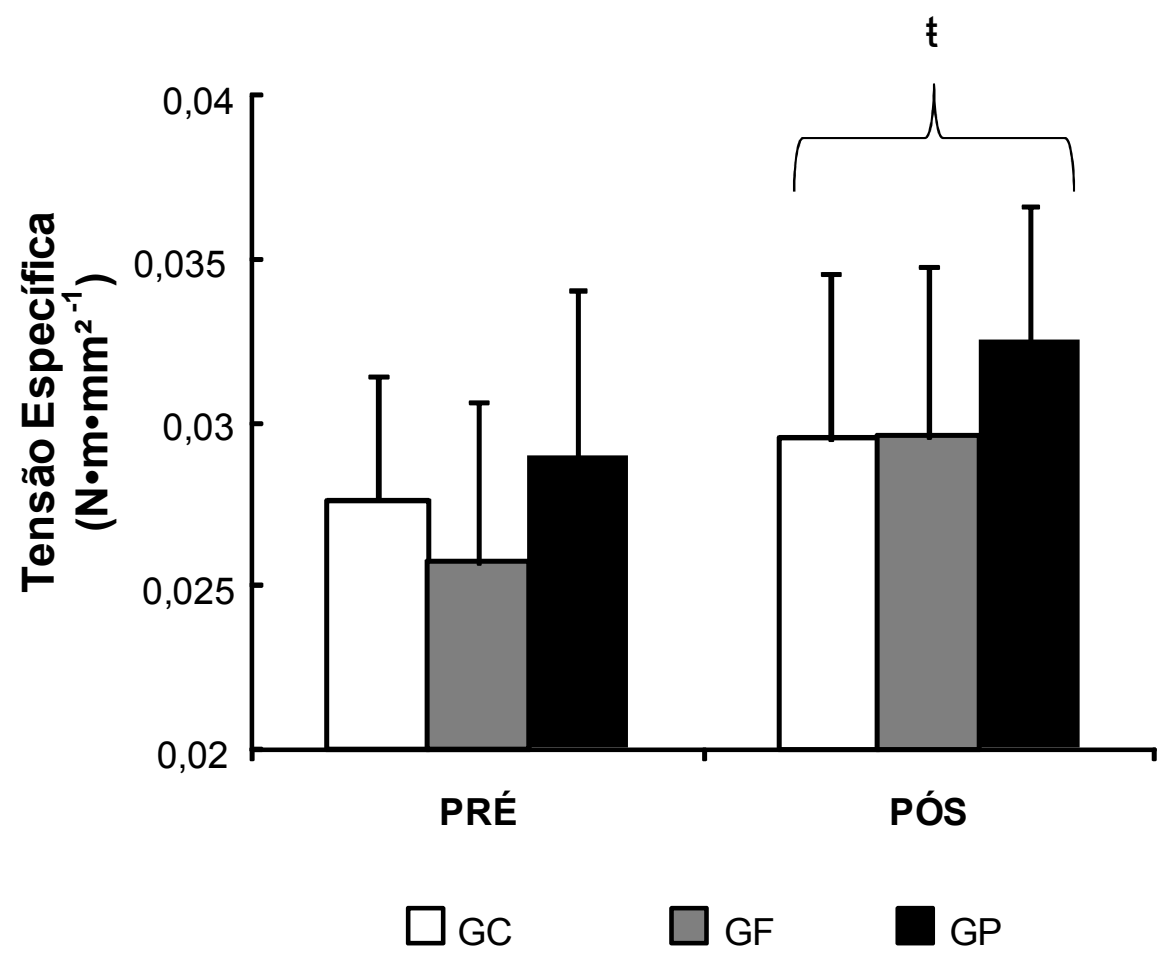

Ł: efeito principal de tempo, $p<0,0006$.

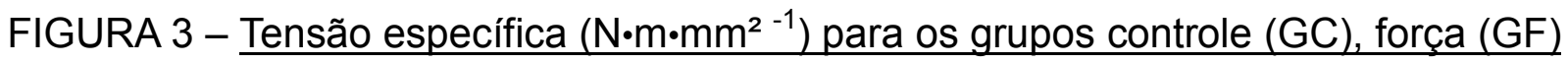
e potência (GP) pré e pós treino.

\section{Força isométrica máxima}

Após o período de treino, foram observados aumentos semelhantes no pico de torque na CVIM de $22,3 \%$ para o GF ( $p<0,0001)$ e de $17,1 \%$ para o GP $(p=0,0008)$. No entanto, esses aumentos não foram suficientes para diferi-los do $G C(p=0,6142)$ no pós treino (FIGURA 4). Em relação ao pico de torque isométrico balístico (CVIBM), foi observado apenas efeito principal de tempo $(p<0,0001)$, sendo os aumentos de $6,3 \%, 19,8 \%$ e 16,4\% para GC, GF e GP, respectivamente (FIGURA 5). 


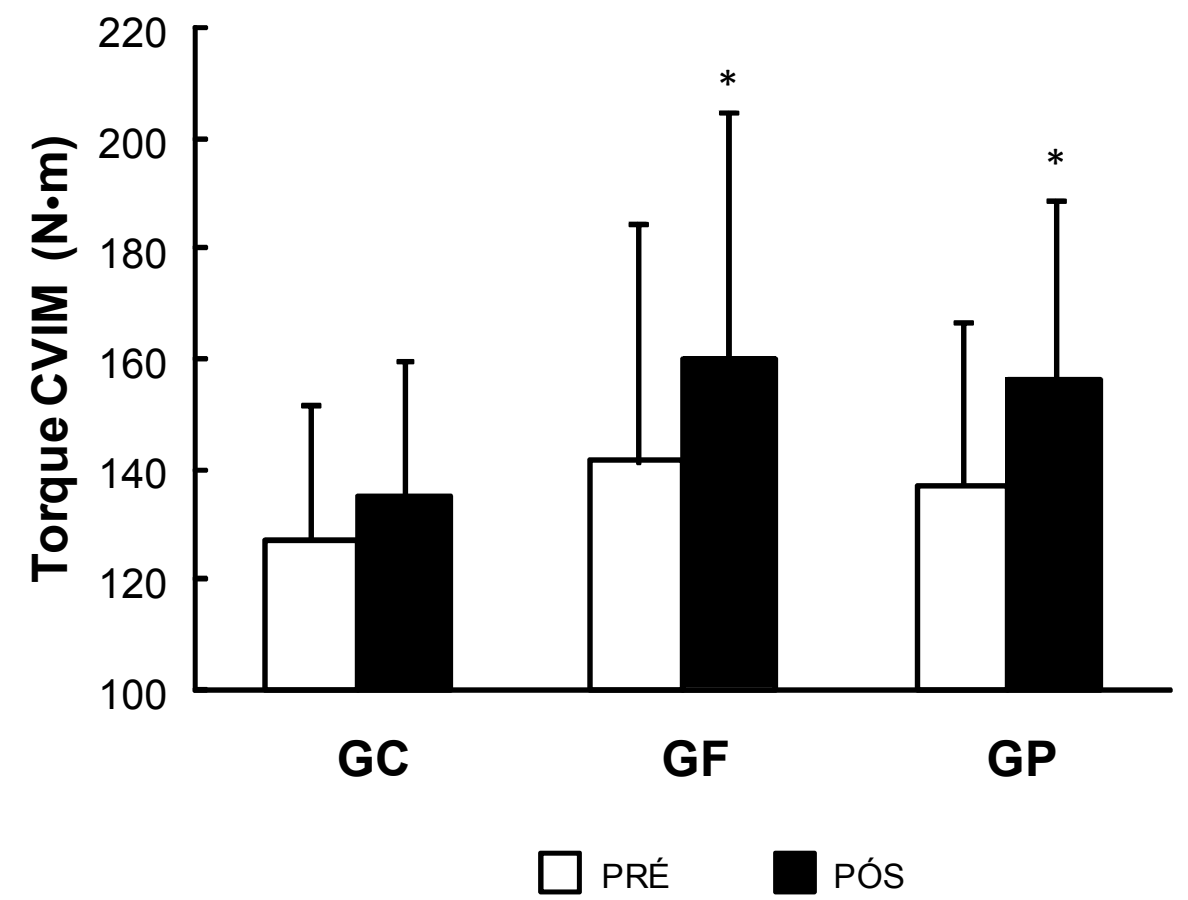

*: valores no pós treino maiores que valores de pré, $p<0,0008$.

FIGURA 4 - Torque isométrico máximo $(\mathrm{N} \cdot \mathrm{m})$ em CVIM para os grupos controle (GC), força (GF) e potência (GP) pré e pós treino. 


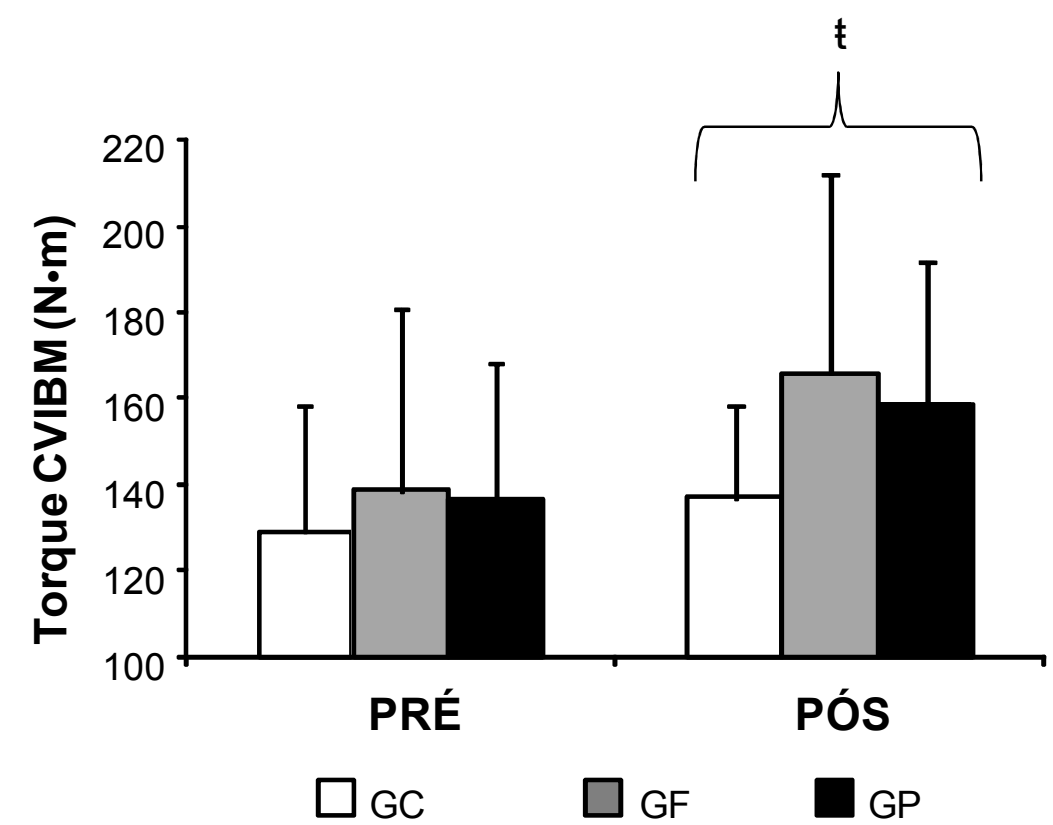

Ł: efeito principal de tempo, $p<0,0001$.

FIGURA 5 - Torque isométrico balístico máximo $(\mathrm{N} \cdot \mathrm{m})$ em CVIBM para os grupos controle (GC), força (GF) e potência (GP) pré e pós treino.

\section{Taxa de desenvolvimento de força}

A TDF100 (nos primeiros 100ms) apresentou apenas efeito principal de tempo ( $p=0,0031$ ), variando de $434,5 \pm 156,5$ para $560,7 \pm 203,3$ no GC; de $562,5 \pm 237,7$ para $637,3 \pm 337,5$ no GF e de $595,0 \pm 199,5$ para $669,7 \pm 282,2 \mathrm{~N} \cdot \mathrm{m} \cdot \mathrm{ms}^{-1}$ no GP, pré e pós intervenção, respectivamente (média $\pm D P$ ). Exceção feita à TDF aos $25 \%$ da CVIBM $(p=0,19)$ e ao tempo até a máxima TDF (tTDF) $(p=0,53)$, que não apresentaram nenhuma modificação, as outras medidas de TDF (TDF máx e TDF aos $50 \%$ e $75 \%$ do torque) tiveram o mesmo comportamento que a TDF100 apresentando apenas efeito principal de tempo $(p<0,0118)$. 


\section{Ativação neural (RMS)}

Tanto na CVIM (TABELA 4) quanto na CVIBM (TABELA 5) foram observados apenas efeitos principais de tempo na RMS do músculo vasto medial (VM) $(p=0,0359$ e $p=0,0299$, respectivamente). Nenhuma modificação foi observada no músculo vasto lateral.

TABELA 4 - Amplitude do sinal eletromiográfico (RMS) nos 500 ms antes e após o pico de torque na CVIM nos músculos vasto medial (VM) e vasto lateral (VL) pré e pós treino para os grupos controle (GC), força (GF) e potência $(G P)$, média $( \pm D P)$.

\begin{tabular}{ccccc}
\hline & \multicolumn{2}{c}{ RMS VM $(\mu \mathrm{V})$} & \multicolumn{2}{c}{ RMS VL $(\boldsymbol{\mu})$} \\
\hline PC & $32,7( \pm 28,4)$ & $37,3( \pm 52,6)$ & $26,5( \pm 19,3)$ & $37,8( \pm 60,1)$ \\
Gós & & & Pré & \\
GF & $40,5( \pm 30,0)$ & $54,6( \pm 37,2)$ & $30,2( \pm 20,7)$ & $44,6( \pm 32,9)$ \\
GP & $77,7( \pm 79,9)$ & $94,1( \pm 101,4)$ & $74,3( \pm 93,2)$ & $83,6( \pm 76,7)$
\end{tabular}

Ł: efeito principal de tempo em relação ao tempo anterior, $p=0,0359$.

TABELA 5 - $\quad$ Amplitude do sinal eletromiográfico (RMS) 500 ms antes e após o pico de torque na CVIBM nos músculos vasto medial (VM) e vasto lateral (VL), pré e pós treino para os grupos controle (GC), força (GF) e potência (GP), média ( $\pm \mathrm{DP})$.

\begin{tabular}{ccccc}
\hline & \multicolumn{2}{c}{ RMS VM $(\mu \mathrm{V})$} & \multicolumn{2}{c}{ RMS VL $(\boldsymbol{\mu} \mathbf{V})$} \\
\hline Pré & Pós $^{\ddagger}$ & Pré & Pós \\
GC & $31,8( \pm 29,2)$ & $33,5( \pm 47,3)$ & $28,7( \pm 22,7)$ & $35,0( \pm 52,2)$ \\
GF & $47,3( \pm 34,4)$ & $61,1( \pm 44,9)$ & $30,7( \pm 25,8)$ & $52,5( \pm 39,3)$ \\
GP & $79,9( \pm 77,9)$ & $95,3( \pm 97,6)$ & $72,6( \pm 94,5)$ & $89,9( \pm 99,1)$ \\
\hline
\end{tabular}

Ł: efeito principal de tempo em relação ao tempo anterior, $p=0,0299$. 


\section{Retardo eletromecânico}

Optamos por não reportar os dados obtidos através da análise por cross correlation pelo fato de termos encontrado muitos valores negativos para o tempo de retardo. Quando o retardo eletromecânico foi medido pela diferença do tempo entre o início do sinal eletromiográfico e o sinal de torque, não observamos modificações no REM no músculo VM em função do treinamento. No entanto, na análise do VL, observamos efeito de interação significante $(p=0,0320)$, sendo que o GP demonstrou uma redução de $32 \%(p=0,0053)$ e o GF de $28 \%(p=0,0354)$, não havendo diferença estatística entre os grupos ( $p=0,7783)$ (TABELA 6).

TABELA 6 - Retardo eletromecânico (REM) nos músculos vasto medial (VM) e vasto lateral (VL) pré e pós treino para os grupos controle (GC), força (GF) e potência (GP), média ( $\pm \mathrm{DP})$.

\begin{tabular}{|c|c|c|c|c|}
\hline & \multicolumn{2}{|c|}{$\begin{array}{l}\text { REM VM } \\
\text { (ms) }\end{array}$} & \multicolumn{2}{|c|}{$\begin{array}{l}\text { REM VL } \\
\text { (ms) }\end{array}$} \\
\hline & Pré & Pós & Pré & Pós \\
\hline GC & $197,4( \pm 85,8)$ & $208,5( \pm 81,6)$ & $207,4( \pm 69,8)$ & $229,6( \pm 65,8)$ \\
\hline GF & $195,5( \pm 80,7)$ & $175,5( \pm 93,8)$ & $212,5( \pm 77,1)$ & $151,7( \pm 102,6)^{*}$ \\
\hline GP & $179,4( \pm 84,0)$ & $147,0( \pm 83,1)$ & $237,1( \pm 72,7)$ & $160,4( \pm 92,8)^{*}$ \\
\hline
\end{tabular}

${ }^{*}$ : valores no pós treino maiores que valores de pré, $p<0,0354$.

\section{Testes funcionais}

O desempenho obtido nos testes funcionais antes e depois do treino está resumido na TABELA 7. Em todos os testes foi observado apenas efeito principal de tempo $(p<0,05)$, ou seja, os três grupos aumentaram igualmente o desempenho em cada teste, mesmo em termos percentuais. 
TABELA 7- Resultados dos testes funcionais de acordo com o grupo de treinamento, pré e pós treino para os grupos controle (GC), força (GF) e potência $(\mathrm{GP})$, média $( \pm \mathrm{DP})$.

\begin{tabular}{ccccccc} 
& \multicolumn{2}{c}{ GC } & \multicolumn{2}{c}{ GF } & \multicolumn{2}{c}{ GP } \\
\cline { 2 - 7 } & Pré & Pós $^{\mathbf{t}}$ & Pré & Pós $^{\mathbf{}}$ & Pré & Pós $^{\mathbf{t}}$ \\
\hline SA (cm) & $-2,8$ & $-1,9$ & $-4,5$ & 0,1 & 4,3 & 8,3 \\
& $( \pm 8,2)$ & $( \pm 8,6)$ & $( \pm 10,3)$ & $( \pm 9,7)$ & $( \pm 8,8)$ & $( \pm 7,0)$ \\
LD (s) & 4,4 & 3,9 & 4,1 & 3,7 & 4,1 & 3,4 \\
& $( \pm 1,3)$ & $( \pm 1,0)$ & $( \pm 1,1)$ & $( \pm 1,0)$ & $( \pm 2,4)$ & $( \pm 0,9)$ \\
LD6 (s) & 2,4 & 2,3 & 2,31 & 2,1 & 2,1 & 1,9 \\
& $( \pm 0,6)$ & $( \pm 0,6)$ & $( \pm 0,6)$ & $( \pm 0,4)$ & $( \pm 0,6)$ & $( \pm 0,5)$ \\
LIV (s) & 6,5 & 5,9 & 6,2 & 5,7 & 6,3 & 5,7 \\
& $( \pm 0,8)$ & $( \pm 0,7)$ & $( \pm 0,5)$ & $( \pm 0,5)$ & $( \pm 0,6)$ & $( \pm 0,5)$ \\
FMI (s) & 10,9 & 9,2 & 11,2 & 8,9 & 10,4 & 8,2 \\
& $( \pm 1,5)$ & $( \pm 1,2)$ & $( \pm 1,3)$ & $( \pm 1,1)$ & $( \pm 1,6)$ & $( \pm 1,2)$ \\
VMAR & 1,8 & 1,9 & 1,9 & 2,0 & 1,9 & 2,1 \\
(m/s) & $( \pm 0,2)$ & $( \pm 0,2)$ & $( \pm 0,2)$ & $( \pm 0,3)$ & $( \pm 0,2)$ & $( \pm 0,2)$ \\
6MC & 574,3 & 598,5 & 575,5 & 598,3 & 596,1 & 612,1 \\
(m) & $( \pm 38,1)$ & $( \pm 56,4)$ & $( \pm 44,8)$ & $( \pm 49,8)$ & $( \pm 43,5)$ & $( \pm 56,5)$ \\
\hline
\end{tabular}

t: médias dos valores pós teste maiores do que os valores pré teste, $p<0,0007$.

Legenda: SA - sentar e alcançar; LD - levantar a partir da posição deitado em decúbito dorsal; LD6 - levantar a partir da posição de 6 apoios; LIV: levantar-ir-e-voltar; FMI: força de membros inferiores (levantar e sentar); VMAR - velocidade da marcha em 30 metros; 6MC distância percorrida durante 6 minutos de caminhada.

\section{DISCUSSÃO}

O presente estudo teve como objetivos comparar os efeitos dos treinamentos de força e de potência nas adaptações neurais e morfológicas de idosos e investigar se as adaptações promovidas estariam associadas à melhora da funcionalidade nessa população. Nossa principal constatação foi a semelhança nas adaptações promovidas por ambos os treinamentos em idosos independentes. No entanto, essas adaptações não se mostraram relacionadas à melhorias na funcionalidade. 
Os aumentos significantes da força dinâmica (GF: 42,7\% e GP: 33,8\%), da força isométrica na CVIM (GF: 22,4\% e GP: 17,1\%), da ASTq (GF: 6,5\% e GP: 3,4\%), assim como a diminuição do REM do VL (GF: 32\% e GP:28\%) não apresentaram diferença estatística entre os grupos GF e GP. Esses resultados indicam que o TF e o TP geraram respostas semelhantes nas variáveis analisadas. Algumas características e mecanismos podem explicar esses resultados.

Quando comparado aos estudos com idosos frágeis, institucionalizados e mais velhos (85 a 97 anos), que tiveram como resposta aumentos de $134 \%$ a $174 \%$ na força dinâmica dos extensores do joelho (FIATARONE et al., 1990; HARRIDGE, KRYGER \& STENSGAARD, 1999), a resposta do GF no presente estudo foi $130 \%$ menor. Por outro lado, idosos fisicamente ativos sem experiência em TF, como em FERRI et al. (2003), apresentaram ganhos similares aos nossos, ao redor de $30 \%$. Da mesma forma, esse resultado também é semelhante ao encontrado por IVEY, TRACY, LEMMER, NESSAIVER, METTER, FOZARD e HURLEY (2000), que reportaram aumento médio de $27 \%$ no teste de $1 \mathrm{RM}$ em idosos totalmente sedentários. E, deste modo, a magnitude de resposta adaptativa não parece estar relacionada ao nível de atividade física do sujeito, mas sim ao status funcional da amostra estudada (idosos independentes x idosos frágeis) (CUOCO et al., 2004). Adicionalmente, a resposta no aumento da força parece estar pautada na presença ou ausência de sessões de familiarização ao teste de 1RM. Os estudos acima citados, com idosos frágeis e institucionalizados (FIATARONE et al., 1990; HARRIDGE et al., 1999) reportam apenas tentativas de familiarização antes do início da sessão de teste propriamente dita. PHILLIPS, BATTERHAM, VALENZUELA e BURKETT (2004) e PLOUTZ-SNYDER e GIAMIS (2001) recomendam de três a oito sessões de familiarização ao teste com idosos para que a medida se torne estável e os efeitos de treinamento não sejam superestimados. PLOUTZ-SNYDER e GIAMIS (2001) observaram aumentos de 22,5\% após o período de familiarização na cadeira extensora em senhoras independentes (66 55 anos), ativas, porém sem experiência em TF $(p<0,05)$. A magnitude do aumento nas idosas $(22,5 \%)$ foi considerável e reflete a importante dimensão do efeito de aprendizado de uma tarefa. Ou seja, a ausência de familiarização com as idosas, nesse caso, poderia superestimar os efeitos de um treinamento em 22,5\%. Em relação a idosos frágeis e 
institucionalizados, não há relatos na literatura a respeito do efeito da familiarização. Porém, com os dados do estudo de PLOUTZ-SNYDER e GIAMIS (2001), podemos sugerir que a idade por si só já demanda sessões de familiarização ao teste de 1RM. Talvez, a ausência de familiarização ao teste de força, a fragilidade e a idade (85 a 97 anos) daqueles idosos expliquem a diferença de $130 \%$ entre os resultados de FIATARONE et al. (1990) e HARRIDGE, KRYGER e STENSGAARD (1999) e o do presente estudo. É importante ressaltar que os estudos que utilizaram idosos saudáveis (IVEY et al., 2000; FERRI et al., 2003) não realizaram um protocolo de familiarização ao teste. Foram realizadas apenas algumas tentativas submáximas com o intuito de familiarizar os sujeitos ao treino e não ao teste máximo. Desse modo, os resultados na força dinâmica máxima do presente estudo sugerem uma maior efetividade do treinamento em relação aos estudos de FERRI et al. (2003) e de IVEY et al. (2000), pois com a familiarização que fizemos, retiramos boa parte do efeito de aprendizagem da tarefa. Logo, as características da amostra e a existência ou não de um protocolo de familiarização ao teste de força dinâmica máxima são observações fundamentais para comparações entre estudos e futuras interpretações.

Parece que um protocolo de familiarização ao teste também pode ter influência na resposta da força isométrica a um programa de treinamento, uma vez que há relatos de aumentos na força isométrica que variam de $9 \%$ a $36 \%$ em decorrência de treinamento (HAKKINEN et al., 2001; REEVES, MAGANARIS \& NARICI, 2005). Os aumentos que observamos na CVIM de $22,4 \%$ no GF e de $17,1 \%$ no GP foram notoriamente superiores aos encontrados por REEVES, MAGANARIS e NARICI (2005). Esses autores avaliaram a força isométrica após 14 semanas de TF e observaram uma resposta de apenas $9 \%$ nessa variável. No estudo, não há relato de protocolo de familiarização ao teste. Nesse sentido, SYMONS, VANDERVOORT, RICE, OVEREND e MARSH (2005) observaram aumento de 7,4\% entre a primeira e segunda sessão de familiarização ao teste isométrico em idosos saudáveis. WALLERSTEIN et al. (submetido) observaram aumentos de $44 \%$ e 33,8\% em testes em rampa (CVIM) e balístico (CVIBM), respectivamente, entre a primeira e a quarta sessão de familiarização e ainda verificaram que são necessárias, pelo menos, três sessões de familiarização a esse tipo de teste para que a medida seja estabilizada. Esses resultados evidenciam o risco de se superestimar os efeitos do treinamento 
dinâmico na ausência de um período de familiarização ao teste isométrico. HAKKINEN et al. (2001) foram os únicos autores que manifestaram preocupação com a familiarização a esse tipo de teste. Embora tenham feito a avaliação através de CVIBM, seus resultados (em média, 21,5\% de aumento) se assemelham bastante aos nossos. No entanto, essa comparação deve ser feita com cautela, pois esses autores aplicaram uma combinação dos treinamentos de força e potência em idosos fisicamente ativos, o que difere substancialmente do presente estudo.

De um modo geral, não foram encontradas diferenças significantes entre GF e GP nos testes dinâmico e isométrico. Talvez, esse resultado esteja relacionado com aspectos do treino, tais como duração e frequência. No entanto, HENWOOD et al. (2008) e FIELDING et al. (2002) observaram o mesmo comportamento, assim como no estudo de LAMAS, UGRINOWITSCH, CAMPOS, AOKI, FONSECA, REGAZZINI, MARISCOT e TRICOLI (2007), com jovens. Nesses estudos a duração variou de oito a 24 semanas, com frequências de duas a três vezes por semana, sugerindo que a duração e a frequência do treinamento não foram os fatores determinantes para a similaridade nas respostas.

Por conta disso, o presente estudo investigou a participação de outras variáveis que fazem parte do processo de produção de força (ASTq, RMS) e suas respostas em relação aos diferentes métodos de treinamento. Dessa maneira, objetivou-se investigar os locais nos quais as adaptações aconteceram a fim de identificar possíveis diferenças. Nesse sentido, um dos fatores que pode ter contribuído para a melhora do desempenho da força foi o aumento constatado na ASTq em ambos os grupos experimentais (em média 6,5\% em GF e 3,4\% em GP, p=0,1790). Esse resultado está dentro dos ganhos descritos na literatura, que variam de 2,7\% a $11 \%$ (FRONTERA et al., 1988; FIATARONE et al., 1990; FIATARONE et al., 1994). Porém, esses estudos analisaram apenas os efeitos do TF. Não encontramos na literatura nenhum estudo que tenha analisado essa variável em resposta ao TP, tão pouco, que tenham feito a comparação entre os métodos com idosos. Tais estudos utilizaram a tomografia computadorizada para a medida de ASTq. Essa medida, embora válida, pode superestimar o real valor em até 30\% (SIPILA \& SUOMINEN, 1993). No presente estudo, a análise da ASTq foi feita através de ressonância nuclear magnética, atualmente reconhecida como "padrão ouro" para essa medida 
(REEVES, MAGANARIS \& NARICI, 2004). Sendo assim, além do pioneirismo na análise dessa medida em resposta ao TP, o presente estudo é um dos primeiros a evidenciar a equivalência entre o TF e o TP em relação à resposta hipertrófica em idosos. A mesma resposta também foi observada por LAMAS et al. (2007) em jovens, após oito semanas de TF e TP. É possível que essa equivalência na resposta hipertrófica decorra da tensão muscular gerada pelos dois tipos de treino, uma vez que ambos são capazes de aumentá-la. Sabidamente, esse aumento da tensão contribui para o acréscimo da força máxima e também da AST (DREYER, BLANCO, SATTLER, SCHROEDER \& WISWELL, 2006). No entanto, os dois métodos de treino elevam a tensão através de estímulos diferentes. O TF através da maior sobrecarga externa, enquanto que o TP, por meio da maior velocidade de execução. As diferenças fundamentais entre esses treinamentos estão nos percentuais de 1RM utilizados e na velocidade de execução dos exercícios. A menor intensidade no TP viabiliza a realização dos movimentos em alta velocidade (KELLIS, ARAMBATZI \& PAPADOPOULOS, 2005). Dessa maneira, ao final da fase concêntrica, é possível que a desaceleração do segmento ocorra mais rapidamente que no TF LAMAS et al. (2007). Assim, a tensão muscular produzida no momento de frenagem pode ser bastante elevada. Por sua vez, essa tensão seria capaz de gerar força a ponto de ser um estímulo para o aumento da ASTq observada LAMAS et al. (2007). Adicionalmente, \{SHEPSTONE, 2005\} em estudo com jovens, observaram maior remodelamento protéico (maior remodelagem de linhas $Z$ ) no treino com velocidade elevada no isocinético (3,66 rad/s) em comparação com o treino em baixa velocidade $(0,35 \mathrm{rad} / \mathrm{s})$. Esses autores atribuem a maior hipertrofia do grupo que treinou a 3,66 $\mathrm{rad} / \mathrm{s}$ à maior remodelagem de linhas $Z$. Embora esse estudo tenha utilizado o treino em velocidade constante e esse treino não ter o controle da fase excêntrica do movimento, a remodelagem de linhas $Z$ foi efetiva a ponto de gerar hipertrofia. Em jovens, o TP já se mostrou efetivo na promoção de hipertrofia (BELL, PETERSEN, MACLEAN, REID \& QUINNEY, 1992) e, como nesse tipo de treino a fase excêntrica é bastante controlada (realizada em 2s, na média), pode-se supor que a remodelagem de linhas $Z$ com esse tipo de treino poderia ser maior e assim, ser suficiente para justificar a hipertrofia observada. 
As adaptações neurais são outros mecanismos responsáveis pelo ganho de força observado no início do treinamento (AAGAARD, SIMONSEN, ANDERSEN, MAGNUSSON \& DYHRE-POULSEN, 2002). Dentre elas, se destaca a ativação neural das fibras musculares, medida no presente estudo pela amplitude do sinal eletromiográfico (RMS). Estudos relatam aumento da ativação neural (EMG de superfície) em decorrência dos treinamentos aqui empregados (HAKKINEN et al., 2001; AAGAARD et al., 2002; ANDERSEN, ANDERSEN, MAGNUSSON, SUETTA, MADSEN, CHRISTENSEN \& AAGAARD, 2005). Contraditoriamente, não foi observado efeito significante no RMS em nenhum dos grupos experimentais do presente estudo. Segundo NARICI, HOPPELER, KAYSER, LANDONI, CLAASSEN, GAVARDI, CONTI e CERRETELLI (1996), isso pode ser atribuído ao grande erro metodológico dessa medida ou até mesmo à capacidade dos voluntários em ativar a totalidade de suas UMs já antes do treinamento. É possível que as sessões de familiarização utilizadas estabilizaram a capacidade de ativar as UMs já no pré-teste. No entanto, isso não implica na inexistência de adaptações neurais durante os programas. Esse pode ser apenas um indício de que talvez a análise da ativação neural não seja a melhor variável a ser mensurada com o intuito de investigar adaptações neurais nessa população. KLASS, BAUDRY e DUCHATEAU (2008) não observaram associação entre a EMG, a TDF e o torque máximo em idosos, porém essa associação existiu em jovens. Nesse sentido, é sabido que idosos apresentam alto nível de co-ativação da musculatura antagonista, o que contribui consideravelmente para o déficit de força (MACALUSO et al., 2002; REEVES, NARICI \& MAGANARIS, 2006). No entanto, estudos já evidenciaram que essa coativação pode ser diminuída por meio do TF e do TP também em idosos (HAKKINEN, KALLINEN, IZQUIERDO, JOKELAINEN, LASSILA, MALKIA, KRAEMER, NEWTON \& ALEN, 1998; HAKKINEN et al., 2000; HAKKINEN et al., 2001), o que otimiza o desenvolvimento da força sem, necessariamente, aumentar a ativação neural. Adicionalmente, uma melhora na coordenação entre os músculos sinergistas também pode ter contribuído para o aumento da força (FERRI et al., 2003). No entanto, nos limitamos apenas a especular sobre essas variáveis, uma vez que nosso estudo não abordou tais medidas. 
Paralelamente, a tensão específica parece ter sido outra variável que manifestou adaptação em decorrência dos protocolos de treino. Ela fornece uma noção mais qualitativa de função muscular, indicando o quanto de força é capaz de ser gerada por área de secção transversa. Segundo JUBRIAS et al. (1997), ela engloba a interação dos sistemas nervoso e muscular. Estudos relatam que idosos apresentam redução na tensão específica que varia de $10 \%$ a $40 \%$ em relação a jovens (KLITGAARD, MANTONI, SCHIAFFINO, AUSONI, GORZA, LAURENTWINTER, SCHNOHR \& SALTIN, 1990; OVEREND et al., 1992; WELLE, TOTTERMAN \& THORNTON, 1996) e que essa redução pode estar associada, entre outros fatores, à perda seletiva de fibras do tipo II (OVEREND et al., 1992). Embora os aumentos da tensão específica no presente estudo não tenham sido significantes $(6,1 \%, 16,6 \%$ e 14,2\%, para GC, GF e GP, respectivamente), são muito semelhantes aos de NARICl et al. (1996), que encontraram 12\% de melhora da tensão específica de jovens (29 $\pm 3,6$ anos) após seis meses de TF e aos de FERRI et al. (2003), que

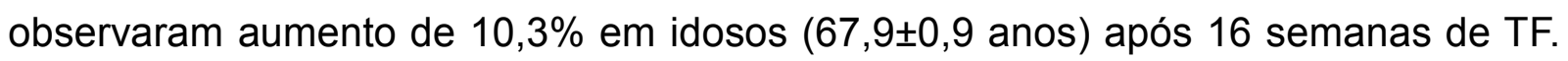
Como não foi produzida resposta na ativação neural, torna-se razoável pensar que a hipertrofia observada tenha interferido não apenas na quantidade de massa muscular, mas na qualidade desse tecido, principalmente no que se refere ao diâmetro das fibras do tipo II, que sabidamente são mais responsivas á hipertrofia e capazes de gerar mais força (IZQUIERDO et al., 1999).Embora não tenhamos realizado biópsia muscular, poderíamos especular sobre um possível aumento no diâmetro das fibras do tipo II, como observaram HAKKINEN et al. (2001) em senhoras fisicamente ativas após seis meses de TF. Adicionalmente, FERRI et al. (2003) atribuem o maior aumento (em valores absolutos) da tensão específica, a aumentos na densidade do tecido contrátil (actina e miosina) ou a diminuição da gordura intermuscular.

Observamos, também, efeito significante no REM do VL nos dois grupos experimentais $(p<0,0354)$. Ou seja, a resposta mecânica passou a ser produzida mais rapidamente. Isso pode ter sido promovido por possíveis alterações no stiffness tendíneo, como já relataram NARICl et al. (1996) 30. Como o grau de rigidez dos tendões (stiffness tendíneo) interfere no tempo necessário para retesar essas estruturas, um aumento do stiffness poderia ser capaz de agir no REM (REEVES et 
al., 2003a). Nesse sentido, REEVES, NARICI e MAGANARIS (2003b) sugerem que o componente tendíneo de idosos pode ser mais responsivo a cargas mecânicas que em jovens. Portanto, se o tendão patelar, por exemplo, tornou-se mais rígido com os treinamentos, a força gerada pela musculatura pôde ser transmitida mais rapidamente e assim, a resposta mecânica aparece mais cedo, refletindo uma diminuição do REM. No entanto, esse resultado não afetou a TDF. Isso pode ser explicado pelo fato de que a TDF está relacionada a outros fatores, incluindo os neurais (VAN CUTSEM et al., 1998; RICARD et al., 2005), além das propriedades tendíneas. Como não foi observado aumento da ativação neural, apenas a melhora do REM não tenha sido suficiente para melhorar a TDF. Adicionalmente, a ausência de melhora no REM do VM, possa ser explicada pela maior ativação desse músculo nos últimos ângulos de extensão do joelho (STENSDOTTER, HODGES, MELLOR, SUNDELIN \& HAGER-ROSS, 2003). De acordo com os exercícios utilizados nos treinamentos, os voluntários praticamente não foram submetidos a tal angulação, o que pode ter minimizado os efeitos nessa musculatura.

Apesar dos resultados apresentados, o presente estudo não evidenciou efeito significante em nenhum dos testes funcionais aplicados. Contrariamente aos estudos de MISZKO et al. (2003) e HENWOOD, RIEK e TAAFFE (2008) que observaram melhoras significantes na funcionalidade de seus voluntários com o TP. Porém, a amostra do estudo de MISZKO et al. (2003) foi composta por idosos institucionalizados e em HENWOOD, RIEK e TAAFFE (2008), a amostra tinha maior média de idade e treinou por mais tempo, do que no presente estudo. PERSCH, UGRINOWITSCH, PEREIRA e RODACKI (2009) observaram melhoras significantes na velocidade da marcha, no comprimento do passo e na cadência através do TF em idosas fisicamente ativas. Tais resultados revelam efeito benéfico na funcionalidade, pois a marcha é uma das principais AVDs. Para esses autores, o melhor funcionamento dos músculos estabilizadores do joelho foi o fator primordial para o aumento da velocidade da marcha. Isso porque, através de análises de regressão, o ganho de força nos extensores do joelho foi responsável por $44 \%$ da melhora no desempenho da marcha. Assim, concluem que o aumento da força máxima é um excelente preditor para mudanças desses parâmetros da marcha e que o TF deve ser recomendado para essa população com o intuito de re-estabelecer o padrão da 
marcha e assim, evitar quedas. Vale ressaltar que a avaliação da marcha foi realizada através de análise cinemática, uma medida bastante sensível e refinada. Por outro lado, assim como no presente estudo, EARLES et al. (2001) também não observaram alterações significantes na bateria de testes funcionais aplicada e atribuíram esse resultado ao alto grau de funcionalidade dos sujeitos já no início do estudo (11,8 segundos no teste de levantar e sentar da cadeira). A não observância de melhoras significantes na funcionalidade no presente estudo pode estar relacionada ao status funcional da amostra assim como na sensibilidade dos testes funcionais aqui aplicados, principalmente quando se trata de idosos altamente funcionais. Os resultados de PERSH et al. (2008) ressaltam a relevância de um teste mais sensível para observação de algum efeito na funcionalidade em idosos altamente funcionais. Os estudos realizados para validação dos testes aqui aplicados (BUTLAND, PANG, GROSS, WOODCOCK \& GEDDES, 1982; PODSIADLO \& RICHARDSON, 1991; ENRIGHT et al., 2003), em sua maioria, utilizaram idosos que já apresentavam algum tipo de deficiência funcional. Assim, o conjunto desses dados nos levam a pensar que, para análise de mudanças na funcionalidade, a característica da população e a metodologia para avaliação dessas adaptações devem ser compatíveis, assim como devem receber atenção quanto à comparação entre estudos.

\section{CONCLUSÃO}

Embora tenhamos utilizado uma metodologia bastante complexa ainda não conseguimos elucidar todas as questões que envolvem as adaptações promovidas pelos TF e TP em idosos, entre elas a resposta da musculatura antagonista e o stiffness tendíneo, que podem individualmente ou em conjunto, contribuir efetivamente para o aumento da força. Parece que para observação de transferência das adaptações promovidas por ambos os treinamentos, deve ser dada atenção ao tipo de avaliação a ser feita e sua adequação às características da população quanto a seu status funcional inicial. No caso de estudos com sujeitos independentes, técnicas mais refinadas devem ser adotadas e, por conta disso não tenhamos observado melhoras em nossa amostra. No entanto, o presente estudo é pioneiro a 
observar a equivalência de resposta em relação à hipertrofia, ao aumento da força (dinâmica e isométrica) e na diminuição do REM do VL através dos TF e TP em idosos independentes. Esses resultados sugerem que mesmo com a utilização de cargas mais leves, o TP é tão eficiente quanto o TF na prevenção da sarcopenia e da redução de força, mostrando-se ser mais uma opção de treinamento, principalmente para idosos com algum tipo de contra indicação ao treinamento de força.

\section{REFERÊNCIAS BIBLIOGRÁFICAS}

AAGAARD, P., MAGNUSSON, P. S., LARSSON, B., KJAER, M. e KRUSTRUP, P. Mechanical muscle function, morphology, and fiber type in lifelong trained elderly. Medicine and Science in Sports and Exercise, Madison, v.39, n.11, p.1989-1996, 2007.

AAGAARD, P., SIMONSEN, E. B., ANDERSEN, J. L., MAGNUSSON, P. e DYHREPOULSEN, P. Increased rate of force development and neural drive of human skeletal muscle following resistance training. Journal of Applied Physiology, Bethesda, v.93, n.4, p.1318-1326, 2002.

ALEXANDER, N. B., ULBRICH, J., RAHEJA, A. e CHANNER, D. Rising from the floor in older adults. Journal of the American Geriatric Society, Los Angeles, v.45, n.5, p.564-569, 1997.

ANDERSEN, L. L., ANDERSEN, J. L., MAGNUSSON, S. P., SUETTA, C., MADSEN, J. L., CHRISTENSEN, L. R. e AAGAARD, P. Changes in the human muscle forcevelocity relationship in response to resistance training and subsequent detraining. Journal of Applied Physiology, Bethesda, v.99, n.1, p.87-94, 2005.

ANDERSEN, L.L. e AAGAARD, P. Influence of maximal muscle strength and intrinsic muscle contractile proprieties on contractile rate of force development. European Journal of Applied Physiology, Berlin, v.96, n.1, p.46-52, 2006.

AVLUND, K., SCHROLL, M., DAVIDSEN, M., LOVBORG, B. e RANTANEN, T. Maximal isometric muscle strength and functional ability in daily activities among 75year-old men and women. Scandinavian Journal of Medicine and Science in Sports, Stockholm, v.4, p.32-40, 1994. 
BARRY, B. K., WARMAN, G. E. e CARSON, R. G. Age-related differences in rapid muscle activation after rate of force development training of the elbow flexors. Experimental Brain Research, Berlin, v.162, n.1, p.122-132, 2005.

BELL,G.J., PETERSEN, S.R., MACLEAN, I., REID, D.C. e QUINNEY, H.A. Effect of high velocity resistance training on peak torque, cross sectional area and myofibrillar ATPase activity. The Journal of Sports Medicine and Physical Fitness, Roma, v.32, n.1, p.122-132, 1992.

BERTOLUCCI, P. H., BRUCKI, S. M., CAMPACCI, S. R. e JULIANO, Y. The MiniMental State Examination in a general population: impact of educational status. Arquivos de Neuropsiquiatria, São Paulo, v.52, n.1, p.1-7, 1994.

BOTTARO, M., MACHADO, S. N., NOGUEIRA, W., SCALES, R. e VELOSO, J. Effect of high versus low-velocity resistance training on muscular fitness and functional performance in older men. European Journal of Applied Physiology, Berlin, v.99, n.3, p.257-264, 2007.

BOTTINELLI, R., CANEPARI, M., REGGIANI, C. e STIENEN, G. J. Myofibrillar ATPase activity during isometric contraction and isomyosin composition in rat single skinned muscle fibres. The Journal of Physiology, London, v.481, n.3, p.663-675, 1994.

BROWN, L. e WHEIR, J. ASEP procedures recommendations I: Accurate assessment of muscular strength and power. Journal of Exercise Physiology, Duluth, v.4, n.3, p.1-21, 2001.

BUTLAND, R. J. A., PANG, J., GROSS, E. R., WOODCOCK, A. A. e GEDDES, D. M. Two-, six-, and 12-minute walking tests in respiratory desease. British Medical Journal, London, v.284, p.1607-1608, 1982.

CLOSE, J. C. Prevention of falls in older people. Disability and Rehabilitation, Abingdon, v.27, n.18-19, p.1061-1071, 2005.

CUOCO, A., CALLAHAN, D. M., SAYERS, S., FRONTERA, W. R., BEAN, J. e FIELDING, R. A. Impact of muscle power and force on gait speed in disabled older men and women. Journals of Gerontololy A Biological Sciences and Medical Sciences, Washington, v.59A, n.11, p.1200-1206, 2004.

DE VOS, N. J., SINGH, N. A., ROSS, D. A., STAVRINOS, T. M., ORR, R. e FIATARONE SINGH, M. A. Optimal load for increasing muscle power during explosive 
resistance training in older adults. Journals of Gerontololy A Biological Sciences and Medical Sciences, Washington, v.60A, n.5, p.638-647, 2005.

DOHERTY, T. J. Invited review: Aging and sarcopenia. Journal of Applied Physiology, Bethesda, v.95, n.4, p.1717-1727, 2003.

DOHERTY, T. J., VANDERVOORT, A. A. e BROWN, W. F. Effects of ageing on the motor unit: a brief review. Canadian Journal of Applied Physiology, Quebec, v.18, n.4, p.331-358, 1993.

DREYER, H. C., BLANCO, C. E., SATTLER, F. R., SCHROEDER, E. T. e WISWELL, R. A. Satellite cell numbers in young and older men 24 hours after eccentric exercise. Muscle and Nerve, Hoboken, v.33, n.2, p.242-253, 2006.

EARLES, D. R., JUDGE, J. O. e GUNNARSSON, O. T. Velocity training induces power-specific adaptations in highly functioning older adults. Archives of Physical Medicine and Rehabilitation, Chicago, v.82, n.7, p.872-878, 2001.

ENRIGHT, P. L. The six-minute walk test. Respiratory Care, New York, v.48, n.8, p.783-785, 2003.

ENRIGHT, P. L., MCBURNIE, M. A., BITTNER, V., TRACY, R. P., MCNAMARA, R., ARNOLD, A. e NEWMAN, A. B. The 6-min walk test: a quick measure of functional status in elderly adults. Chest, Northbrook, v.123, n.2, p.387-398, 2003.

FERRI, A., SCAGLIONI, G., POUSSON, M., CAPODAGLIO, P., VAN HOECKE, J. e $\mathrm{NARICl}, \mathrm{M}$. V. Strength and power changes of the human plantar flexors and knee extensors in response to resistance training in old age. Acta Physiologica Scandinavica, Stockholm, v.177, n.1, p.69-78, 2003.

FIATARONE, M. A., MARKS, E. C., RYAN, N. D., MEREDITH, C. N., LIPSITZ, L. A. e EVANS, W. J. High-intensity strength training in nonagenarians. Effects on skeletal muscle. JAMA: The Journal of American Medical Association, Chicago, v.263, n.22, p.3029-3034, 1990.

FIATARONE, M. A., O'NEILL, E. F., RYAN, N. D., CLEMENTS, K. M., SOLARES, G. R., NELSON, M. E., ROBERTS, S. B., KEHAYIAS, J. J., LIPSITZ, L. A. e EVANS, W. $J$. Exercise training and nutritional supplementation for physical frailty in very elderly people. New England Journal of Medicine, Massachusetts, v.330, n.25, p.17691775, 1994. 
FIELDING, R. A., LEBRASSEUR, N. K., CUOCO, A., BEAN, J., MIZER, K. e FIATARONE SINGH, M. A. High-velocity resistance training increases skeletal muscle peak power in older women. Journal of the American Geriatric Society, Los Angeles, v.50, n.4, p.655-662, 2002.

FLECK, S. J., KRAEMER, W. J. Fundamentos do Treinamento de Força Muscular. In: Treinamento de Força para Idosos. $3^{a}$ Edição. Porto Alegre: Artmed, 2006. p.309365.

FOLSTEIN, M. F., FOLSTEIN, S. E. e MCHUGH, P. R. "Mini-mental state". A practical method for grading the cognitive state of patients for the clinician. Journal of Psychiatric Research, Arlington, v.12, n.3, p.189-198, 1975.

FRONTERA, W. R. e BIGARD, X. The benefits of strength training in the elderly. Science and Sports, France, v.17, p.109-116, 2002.

FRONTERA, W. R., MEREDITH, C. N., O'REILLY, K. P., KNUTTGEN, H. G. e EVANS, W. J. Strength conditioning in older men: skeletal muscle hypertrophy and improved function. Journal of Applied Physiology, Bethesda, v.64, n.3, p.10381044, 1988.

FRONTERA, W. R., SUH, D., KRIVICKAS, L. S., HUGHES, V. A., GOLDSTEIN, R. e ROUBENOFF, R. Skeletal muscle fiber quality in older men and women. American Journal of Physiology - Cell Physiology, Stanford, v.279, n.3, p.C611-618, 2000.

GURALNIK, J. M., FERRUCCI, L., SIMONSICK, E. M., SALIVE, M. E. e WALLACE, R. B. Lower-extremity function in persons over the age of 70 years as a predictor of subsequent disability. New England Journal of Medicine, Massachusetts, v.332, n.9, p.556-561, 1995.

HAKKINEN, K., ALEN, M., KALLINEN, M., IZQUIERDO, M., JOKELAINEN, K., LASSILA, H. e MALKIA, E. Muscle CSA, force production, and activation of leg extensors during isometric and dynamic actions in middle-aged and elderly men and women. Journal of Aging and Physical Activity, Champaign, v.6, n.3, p.232-247, 1998.

HAKKINEN, K., ALEN, M., KALLINEN, M., NEWTON, R. U. e KRAEMER, W. J. Neuromuscular adaptation during prolonged strength training, detraining and restrength-training in middle-aged and elderly people. European Journal of Applied Physiology, Berlin, v.83, n.1, p.51-62, 2000. 
HAKKINEN, K. e HAKKINEN, A. Neuromuscular adaptations during intensive strength training in middle-aged and elderly males and females. Electromyography and Clinical Neurophysiology, Limerick, v.35, n.3, p.137-147, 1995.

HAKKINEN, K., KALLINEN, M., IZQUIERDO, M., JOKELAINEN, K., LASSILA, H., MALKIA, E., KRAEMER, W. J., NEWTON, R. U. e ALEN, M. Changes in agonistantagonist EMG, muscle CSA, and force during strength training in middle-aged and older people. Journal of Applied Physiology, Bethesda, v.84, n.4, p.1341-1349, 1998.

HAKKINEN, K., KRAEMER, W. J., NEWTON, R. U. e ALEN, M. Changes in electromyographic activity, muscle fibre and force production characteristics during heavy resistance/power strength training in middle-aged and older men and women. Acta Physiologica Scandinavica, Stockholm, v.171, n.1, p.51-62, 2001.

HARRIDGE, S. D., KRYGER, A. e STENSGAARD, A. Knee extensor strength, activation, and size in very elderly people following strength training. Muscle and Nerve, Hoboken, v.22, n.7, p.831-9, 1999.

HENNEMAN, E. The size-principle: a deterministic output emerges from a set of probabilistic connections. The Journal of Experimental Biology, Cambridge, v.115, p.105-112, 1985.

HENWOOD, T. R., RIEK, S. e TAAFFE, D. R. Strength versus muscle power-specific resistance training in community-dwelling older adults. Journals of Gerontololy A Biological Sciences and Medical Sciences, Washington, v.63A, n.1, p.83-91, 2008.

HOTATIAN, S. R. Identificação de suspeitos de demência em três distritos do município de São Paulo. 2002. 114f. Dissertação (Mestrado em Ciências Médicas) Faculdade de Medicina de São Paulo, Universidade de São Paulo, São Paulo.

HURLEY, B. F. e ROTH, S. M. Strength training in the elderly: effects on risk factors for age-related diseases. Sports Medicine, Auckland, v.30, n.4, p.249-268, 2000.

IVEY, F. M., TRACY, B. L., LEMMER, J. T., NESSAIVER, M., METTER, E. J., FOZARD, J. L. e HURLEY, B. F. Effects of strength training and detraining on muscle quality: age and gender comparisons. Journals of Gerontololy A Biological Sciences and Medical Sciences, Washington, v.55B, n.3, p.152-157, 2000. 
IZQUIERDO, M., AGUADO, X., GONZALEZ, R., LOPEZ, J. L. e HAKKINEN, K. Maximal and explosive force production capacity and balance performance in men of different ages. European Journal of Applied Physiology and Occupational Physiololy, Berlin, v.79, n.3, p.260-267,1999.

JUBRIAS, S. A., ODDERSON, I. R., ESSELMAN, P. C. e CONLEY, K. E. Decline in isokinetic force with age: muscle cross-sectional area and specific force. Pflugers Archiv European Journal of Physiology, Berlin, v.434, n.3, p.246-253, 1997.

KADI, F., CHARIFI, N., DENIS, C. e LEXELL, J. Satellite cells and myonuclei in young and elderly women and men. Muscle and Nerve, Hoboken, v.29, n.1, p.120-127, 2004.

KELLIS, E., ARAMBATZI, F. e PAPADOPOULOS, C. Effects of load on ground reaction force and lower limb kinematics during concentric squats. Journal of Sports Sciences, Oxon, v.23, n.10, p.1045-1055, 2005.

KIM, J. S., WILSON, J. M. e LEE, S. R. Dietary implications on mechanisms of sarcopenia: roles of protein, amino acids and antioxidants. The Journal of Nutritional Biochemestry, Stoneham, v.21, n.1, p.1-13, 2010.

KLASS, M., BAUDRY, S. e DUCHATEAU, J. Age-related decline in rate of torque development is accompanied by lower maximal motor unit discharge frequency during fast contractions. Journal of Applied Physiology, Bethesda, v.104, n.3, p.739-746, 2008.

KLITGAARD, H., MANTONI, M., SCHIAFFINO, S., AUSONI, S., GORZA, L., LAURENT-WINTER, C., SCHNOHR, P. e SALTIN, B. Function, morphology and protein expression of ageing skeletal muscle: a cross-sectional study of elderly men with different training backgrounds. Acta Physiologica Scandinavica, Stockholm, v.140, n.1, p.41-54, 1990.

KOSTKA, T. Quadriceps maximal power and optimal shortening velocity in 335 men aged 23-88 years. European Journal of Applied Physiology, Berlin, v.95, n.2-3, p.140-145, 2005.

KYROLAINEN, H., AVELA, J., MCBRIDE, J. M., KOSKINEN, S., ANDERSEN, J. L., SIPILA, S., TAKALA, T. E. e KOMI, P. V. Effects of power training on muscle structure and neuromuscular performance. Scandinavian Journal of Medicine and Science in Sports, Stockholm, v.15, n.1, p.58-64, 2005. 
LAMAS, L., UGRINOWITSCH, C., CAMPOS, G. E. R., AOKI, M. S., FONSECA, R., REGAZZINI, M., MARISCOT, A. S. e TRICOLI, V. A. Treinamento de força máxima $x$ treinamento de potência: alterações no desempenho e adaptações morfológicas. Revista Brasileira de Educação Física e Esporte, São Paulo, v.21, n.4, p.331-340, 2007.

LARSSON, L. Histochemical characteristics of human skeletal muscle during aging. Acta Physiologica Scandinavica, Stockholm, v.117, n.3, p.469-471, 1983.

LARSSON, L. e SALVIATI, G. Effects of age on calcium transport activity of sarcoplasmic reticulum in fast- and slow-twitch rat muscle fibres. The Journal of Physiology, London, v.419, p.253-264, 1989.

LEXELL, J., TAYLOR, C. C. e SJOSTROM, M. What is the cause of the ageing atrophy? Total number, size and proportion of different fiber types studied in whole vastus lateralis muscle from 15- to 83-year-old men. Journal of Neurological Sciences, Amsterdam, v.84, n.2-3, p.275-294, 1988.

MACAlUSO, A., NIMMO, M. A., FOSTER, J. E., COCKBURN, M., MCMILLAN, N. C. e DE VITO, G. Contractile muscle volume and agonist-antagonist coactivation account for differences in torque between young and older women. Muscle and Nerve, Hoboken, v.25, n.6, p.858-863, 2002.

MAKI, B. E. e MCILROY, W. E. Control of rapid limb movements for balance recovery: age-related changes and implications for fall prevention. Age and Ageing, Dordrecht, v.35, n.S2, p.ii I 2-ii I 8, 2006.

MATTIELLO-ZVERZUT, A. C. Histopatologia do músculo esquelético no processo de envelhecimento e fundamentação para a prática terapêutica de exercícios físicos e prevenção da sarcopenia. Revista de Fisioterapia: Universidade de São Paulo, São Paulo, v.10, n.1, p.24-33, 2003.

MION, D., KOHLMANN, O., MACHADO, C., AMODEO, C., GOMES, M., PRAXEDES, J., NOBRE, F., BRANDÃO, A., ZANELLA, M. e GUSMÃO, J. V Diretrizes Brasileiras de Hipertensão Arterial Sociedade Brasileira de Hipertensão, 2006, São Paulo, 2006. 121-156 p.

MISZKO, T. A., CRESS, M. E., SLADE, J. M., COVEY, C. J., AGRAWAL, S. K. e DOERR, C. E. Effect of strength and power training on physical function in community-dwelling older adults. Journals of Gerontololy A Biological Sciences and Medical Sciences, Washington, v.58, n.2, p.171-175. 2003. 
MORITANI, T. Neuromuscular adaptations during the acquisition of muscle strength, power and motor tasks. Journal of Biomechanics, New York, v.26 Suppl 1, p.95107. 1993.

MORLEY, J. E., BAUMGARTNER, R. N., ROUBENOFF, R., MAYER, J. e NAIR, K. S. Sarcopenia. Journal of Laboratory and Clinical Medicine, Saint Louis, v.137, n.4, p.231-243, 2001.

NARICI, M. V., HOPPELER, H., KAYSER, B., LANDONI, L., CLAASSEN, H., GAVARDI, C., CONTI, M. e CERRETELLI, P. Human quadriceps cross-sectional area, torque and neural activation during 6 months strength training. Acta Physiologica Scandinavica, Stockholm, v.157, n.2, p.175-186, 1996.

OVEREND, T. J., CUNNINGHAM, D. A., KRAMER, J. F., LefCOE, M. S. e PATERSON, D. H. Knee extensor and knee flexor strength: cross-sectional area ratios in young and elderly men. Journal of Gerontology, Washington, v.47, n.6, p.M204-210, 1992.

PERSCH, L. N., UGRINOWITSCH, C., PEREIRA, G. e RODACKI, A. L. Strength training improves fall-related gait kinematics in the elderly: a randomized controlled trial. Clinical Biomechanics (Briostol, Avon), England, v.24, n.10, p.819-825, 2009.

PHILLIPS, W. T., BATTERHAM, A. M., VALENZUELA, J. E. e BURKETT, L. N. Reliability of maximal strength testing in older adults. Archives of Physical Medicine and Rehabilitation, Chicago, v.85, n.2, p.329-334, 2004.

PLOUTZ-SNYDER, L. L. e GIAMIS, E. L. Orientation and familiarization to 1RM strength testing in old and young women. Journal of Strength Conditioning Research, Champaign, v.15, n.4, p.519-523, 2001.

PODSIADLO, D. e RICHARDSON, S. The timed "Up \& Go": a test of basic functional mobility for frail elderly persons. Journal of the American Geriatrics Society, Los Angeles, v.39, n.2, p.142-148, 1991.

RATAMESS, N. A., ALVAR, B. A., EVETOCH, T. K., HOUSH, T. J., KIBLER, W. B., KRAEMER, W. J. e TRIPLETT, M. T. American College of Sports Medicine position stand. Progression models in resistance training for healthy adults. Medicine and Science in Sports and Exercise, Madison, v.41, n.3, p.687-708, 2009. 
REEVES, N. D., MAGANARIS, C. N. e NARICI, M. V. Effect of strength training on human patella tendon mechanical properties of older individuals. The Journal of Physiology, London, v.548, n.3, p.971-981, 2003a.

REEVES, N. D., MAGANARIS, C. N. e NARICI, M. V. Ultrasonographic assessment of human skeletal muscle size. European Journal of Applied Physiology, Berlin, v.91, n.1, p.116-118, 2004.

REEVES, N. D., MAGANARIS, C. N. e NARICI, M. V. Plasticity of dynamic muscle performance with strength training in elderly humans. Muscle and Nerve, Hoboken, v.31, n.3, p.355-364. 2005.

REEVES, N. D., NARICI, M. V. e MAGANARIS, C. N. Strength training alters the viscoelastic properties of tendons in elderly humans. Muscle and Nerve, Hoboken, v.28, n.1,p.74-81, 2003b.

REEVES, N. D., NARICI, M. V. e MAGANARIS, C. N. Effect of resistance training on skeletal muscle-specific force in elderly humans. Journal of Applied Physiology, Bethesda, v.96, n.3, p.885-892, 2004.

REEVES, N. D., NARICI, M. V. e MAGANARIS, C. N. Musculoskeletal adaptations to resistance training in old age. Manual Therapy, Scotland, v.11, n.3, p.192-6, 2006.

RICARD, M. D., UGRINOWITSCH, C., PARCELL, A. C., HILTON, S., RUBLEY, M. D., SAWYER, R. e POOLE, C. R. Effects of rate of force development on EMG amplitude and frequency. International Journal of Sports Medicine, Stuttgart, v.26, n.1, p.6670, 2005.

RIKLI, R. E. Reliability, validity, and methodological issues in assessing physical activity in older adults. Research Quartely for Exercise and Sport, Danvers, v.71, n.2 Suppl, p.S89-96, 2000.

RIKLI, R. E. e JONES, J. Development and validation of a functional fitness test for community-residing older adults. Journal of Aging and Physical Activity, Champaign, v.7, n.2, p.129-161, 1999.

ROOS, M. R., RICE, C. L. e VANDERVOORT, A. A. Age-related changes in motor unit function. Muscle and Nerve, Hoboken, v.20, n.6, p.679-90, 1997.

SALE, D. G. Neural adaptation to resistance training. Medicine and Science in Sports and Exercise, Madison, v.20, n.5 Suppl, p.S135-45, 1988. 
SHEPSTONE, T. N., TANG, J. E., DALLAIRE, S., SCHUENKE, M. D., STARON, R. S. e PHILLIPS, S. M. Short-term high- vs. low-velocity isokinetic lengthening training results in greater hypertrophy of the elbow flexors in young men. Journal of Applied Physiology, Bethesda, v.98, n.5,p.1768-76, 2005.

SHUMWAY-COOK, A., BRAUER, S. e WOOLLACOTT, M. Predicting the probability for falls in community-dwelling older adults using the Timed Up \& Go Test. Physical Therapy, Alexandria, v.80, n.9, p.896-903, 2000.

SIPILA, S. e SUOMINEN, H. Muscle ultrasonography and computed tomography in elderly trained and untrained women. Muscle and Nerve, Hoboken, v.16, n.3, p.294300, 1993.

SKELTON, D. A., GREIG, C. A. e DAVIES, J. M. e YOUNG, A. Strength, power and related functional ability of healthy people aged 65-89 years. Age and Ageing, Dordrecht v.23, n.5, p.371-377, 1994.

STENSDOTTER, A.H., HODGES, P.W., MELLOR, R., SUNDELIN, G. e HAGERROSS, C. Quadriceps activation on closed ans in open kinetic chain exercise. Medicine and Science in Sports and Exercise, Madison, v.35, n.12, p.2043-2047, 2003.

STEVENS, J. A. Falls among older adults--risk factors and prevention strategies. Journal of Safety Research, United States, v.36, n.4, p.409-411, 2005.

SUEtTA, C., AAGAARD, P., ROSted, A., JAKOBSEN, A. K., DUUS, B., KJAER, M. e MAGNUSSON, S. P. Training-induced changes in muscle CSA, muscle strength, EMG, and rate of force development in elderly subjects after long-term unilateral disuse. Journal of Applied Physiology, Bethesda, v.97, n.5, p.1954-1961, 2004.

SYMONS, T. B., VANDERVOORT, A. A., RICE, C. L., OVEREND, T. J. e MARSH, G. $D$. Reliability of a single-session isokinetic and isometric strength measurement protocol in older men. Journals of Gerontololy A Biological Sciences and Medical Sciences, Washington, v.60, n.1, p.114-119, 2005.

THOMPSON, L. V. Effects of age and training on skeletal muscle physiology and performance. Physical Therapy, Alexandria, v.74, n.1,p.71-81, 1994. 
TINETTI, M. E., SPEECHLEY, M. e GINTER, S. F. Risk factors for falls among elderly persons living in the community. New England Journal of Medicine, Massachusetts, v.319, n.26, , p.1701-1707, 1988.

TINETTI, M. E. e WILLIAMS, C. S. Falls, injuries due to falls, and the risk of admission to a nursing home. New England Journal of Medicine, Massachusetts, v.337, n.18, p.1279-1284, 1997.

TOMLINSON, B. E. e IRVING, D. The numbers of limb motor neurons in the human lumbosacral cord throughout life. Journal of the Neurological Sciences, v.34, n.2, Nov, p.213-219. 1977.

VAN CUTSEM, M., DUCHATEAU, J. e HAINAUT, K. Changes in single motor unit behaviour contribute to the increase in contraction speed after dynamic training in humans. The Journal of Physiology, London, v.513, n.1, p.295-305, 1998.

VANDERVOORT, A. A. Aging of the human neuromuscular system. Muscle and Nerve, Hoboken, v.25, n.1, p.17-25, 2002.

VELLAS, B. J., WAYNE, S. J., ROMERO, L., BAUMGARTNER, R. N., RUBENSTEIN, L. Z. e GARRY, P. J. One-leg balance is an important predictor of injurious falls in older persons. Journal of the American Geriatrics Society, Los Angeles, v.45, n.6, p.735-738, 1997.

VERDIJK, L. B., KOOPMAN, R., SCHAART, G., MEIJER, K., SAVELBERG, H. H. e VAN LOON, L. J. Satellite cell content is specifically reduced in type II skeletal muscle fibers in the elderly. American Journal of Physiology: Endocrinology and Metabolism, Bethesda, v.292, n.1, p.E151-157, 2007.

VERDU, E., CEBALLOS, D., VILCHES, J. J.e NAVARRO, X. Influence of aging on peripheral nerve function and regeneration. Journal of the Peripheral Nervous System, Oxford, v.5, n.4, p.191-208, 2000.

WALLERSTEIN, L.F., BARROSO, R., TRICOLI, V., MELLO, M.T.e UGRINOWITSCH, C. The influence of familiarization sessions on the stability of ramp and ballistic isometric torque in the elderly. Journal of Aging and Physical Activity, Champaign, (no prelo).

WELLE, S., TOTTERMAN, S. e THORNTON, C. Effect of age on muscle hypertrophy induced by resistance training. Journals of Gerontololy A Biological Sciences and Medical Sciences, Washington, v.51, n.6, p.M270-275, 1996. 
WHITNEY, S. L., WRISLEY, D. M., MARCHETTI, G. F., GEE, M. A., REDFERN, M. S. e FURMAN, J. M. Clinical measurement of sit-to-stand performance in people with balance disorders: validity of data for the Five-Times-Sit-to-Stand Test. Physical Therapy, Alexandria, v.85, n.10, p.1034-1045, 2005. 


\section{ANEXOS}

ANEXO I - Termo de consentimento informado

\section{ESCOLA DE EDUCAÇÃO FÍSICA E ESPORTE \\ DA}

UNIVERSIDADE DE SÃO PAULO

TERMO DE CONSENTIMENTO LIVRE E ESCLARECIDO

(Instruções para preenchimento no verso)

\section{I - DADOS DE IDENTIFICAÇÃO DO SUJEITO DA PESQUISA OU RESPONSÁVEL LEGAL}

1. NOME DO INDIVÍDUO:

DOCUMENTO DE IDENTIDADE N ${ }^{\circ}$ : DATA NASCIMENTO:

ENDEREÇO: 1 1 BAIRRO: CIDADE :

CEP: TELEFONE: DDD SEXO: $M() F($ ) No: APTO:

2.RESPONSÁVEL LEGAL:

NATUREZA (grau de parentesco, tutor, curador, etc.): DOCUMENTO DE IDENTIDADE: SEXO: $M($ ) $F($ ) DATA NASCIMENTO: ENDEREÇO: $N^{0}:$ APTO: BAIRRO: CIDADE :

CEP: TELEFONE: DDD

\section{II - DADOS SOBRE A PESQUISA CIENTÍFICA}

1. TÍTULO DO PROJETO DE PESQUISA "Influência dos treinamentos de força e de potência nas adaptações neurais, morfológicas e na funcionalidade em idosos".

2. PESQUISADOR RESPONSÁVEL: Prof. Dr. Carlos Ugrinowitsch

3. CARGO/FUNÇÃO: Professor Doutor 


\title{
4. AVALIAÇÃO DO RISCO DA PESQUISA:
}

\author{
RISCO MÍNIMO ( ) RISCO MÉDIO ( ) \\ RISCO BAIXO (X) RISCO MAIOR ( )
}

(probabilidade de que o indivíduo sofra algum dano como consequência imediata ou tardia do estudo)

5. DURAÇÃO DA PESQUISA

Vinte e sete (27) semanas. Equivalente a seis meses e três semanas.

\section{III - EXPLICAÇÕES DO PESQUISADOR AO INDIVÍDUO OU SEU REPRESENTANTE LEGAL SOBRE A PESQUISA, CONSIGNANDO:}

1. Justificativa e os objetivos da pesquisa:

O senhor (a) foi convidado (a) a participar de um protocolo de pesquisa que tem como objetivo investigar os efeitos dos treinamentos de força e potência nas adaptações neuromusculares (neurais e morfológicas) e na rigidez (stiffness) de estruturas corporais em idosos. Além de avaliar como as adaptações decorrentes estão associadas às suas dificuldades em realizar atividades da vida diária e em caminhar. Também estudaremos o comportamento da sua pressão arterial com o treinamento. Os resultados obtidos no estudo poderão ser úteis na escolha do tipo de treino mais adequado para o aumento da funcionalidade em idosos. Sendo assim, o (a) senhor (a) foi selecionado, dentre os voluntários, para participar do estudo devido ao seu grau de independência na execução das atividades da vida diária e à sua boa avaliação médica que lhe permite participar de um protocolo de exercícios físicos.

2. Procedimentos que serão utilizados e propósitos, incluindo a identificação dos procedimentos que são experimentais:

O protocolo do estudo consistirá num total de 27 semanas. Na primeira semana acontecerão os testes iniciais: bateria de testes de força das pernas e dos braços, flexibilidade, agilidade e resistência aeróbia. Contração voluntária isométrica máxima (CVIM) no dinamômetro isocinético (aparelho para avaliação da força), no qual o (a) senhor (a) executará duas repetições e será instruído (a) a atingir o nível de força máxima em dois segundos, devendo manter esse nível por três segundos; contração isométrica máxima balística (CVIMB), com o mesmo procedimento do teste anterior, porém, o (a) senhor (a) será instruído (a) a atingir o pico de força o mais rápido possível e mantê-lo por 3 segundos. Nesses dois últimos testes será feita concomitantemente a avaliação da atividade dos músculos empregados durante a realização dos movimentos, procedimento denominado eletromiografia. Para isso sua pele será devidamente preparada (retirada de pêlos, raspagem e limpeza) para a colocação de pequenos eletrodos de superfície, que estarão conectados a um 
sistema computadorizado que captará os sinais de atividade muscular; teste de maior velocidade de marcha em $30 \mathrm{~m}$ em duas tentativas, no qual a velocidade média será o quociente entre a distância percorrida e o tempo gasto. Neste teste o (a) senhor (a) não poderá utilizar auxílio de muletas, bengalas, corrimão etc; teste de mecânica da marcha sob a plataforma de força em um laboratório de análise da marcha, onde o (a) senhor (a) deverá vestir roupas confortáveis, que não atrapalhem os movimentos (com preferência para shorts e camiseta), no qual seus movimentos serão filmados e gravados. Sua privacidade será mantida, uma vez que as imagens serão tratadas de maneira que não visualizaremos seu corpo, mas sim uma representação dele; exame de ressonância nuclear magnética para verificação da área de secção transversa do músculo quadríceps e da rigidez do tendão do quadríceps. Na segunda semana o (a) senhor (a) participará de um sorteio aleatório, no qual será designado (a) a fazer parte de um dos seguintes grupos: Força (GF), Potência (GP) e Controle (GC). Os sujeitos sorteados para os dois primeiros grupos serão submetidos a um protocolo de exercícios, ora de força, ora de potência de acordo com o sorteio, enquanto que os sujeitos sorteados para os grupos controle não farão nenhum dos tipos de treinamento. Nas 16 semanas seguintes acontecerá o treinamento, que consistirá de 32 sessões para os sujeitos dos grupos de treinamento. Na última semana, os testes finais serão realizados em todos os sujeitos, repetindo os procedimentos da primeira semana.

\section{Desconforto e riscos esperados:}

Os riscos envolvidos na participação deste estudo são baixos. Todos os testes desse estudo são seguros e bem tolerados. Porém alguns desconfortos podem ocorrer como: sentir um certo cansaço e dor muscular passageira após o teste ergomérico. No entanto este desconforto será mínimo e não o (a) impedirá de prosseguir com as suas atividades diárias; o senhor (a) poderá sentir dor, principalmente na musculatura dos membros inferiores e articulação do joelho tardiamente (24 - 72 horas após a sessão de treino) decorrente do protocolo de treinamento, é uma resposta considerada normal. Caso esse desconforto aconteça, ele se manifestará após as primeiras sessões e, talvez, somente após as sessões com incremento de intensidade. Nas sessões subseqüentes a possibilidade de ocorrência de dor é muito pequena. No entanto, em caso de nova ocorrência, ela será menos intensa que na primeira sessão (esse é um dos efeitos do treinamento). O aparelho de monitorização da pressão arterial de 24 horas poderá causar um certo incômodo e o (a) senhor (a) poderá sentir alguma dificuldade para dormir com ele. A medida do débito cardíaco poderá trazer a sensação de "boca seca" durante a respiração do gás carbônico. Além disso, o teste ergométrico poderá encontrar algum problema cardíaco incipiente, mas ele será acompanhado por um médico e será monitorado para evitar qualquer problema. 
4. Benefícios que poderão ser obtidos:

Não haverá compensação financeira pela sua participação neste estudo. O (a) senhor (a) receberá um relatório completo sobre seu desempenho e participação, assim como do resultado final do estudo.

5. Procedimentos alternativos que possam ser vantajosos para o indivíduo:

Não será possível realizar qualquer procedimento alternativo em substituição aos procedimentos acima mencionados.

\section{IV - ESCLARECIMENTOS DADOS PELO PESQUISADOR SOBRE GARANTIAS DO SUJEITO DA PESQUISA:}

Os pesquisadores responsáveis pelo estudo se colocam a disposição para esclarecer, a qualquer momento, as possíveis dúvidas sobre os procedimentos, riscos e benefícios proporcionados pelo estudo. Além disso, o (a) senhor (a) tem o direito de se retirar a qualquer momento do estudo sem que isso lhe proporcione qualquer prejuízo ou transtorno. As informações obtidas durante o estudo ficarão guardadas sob sigilo e privacidade absolutos. Em caso de qualquer emergência médica, ou lesão decorrente do treinamento os responsáveis pelo estudo lhe acompanharão ao Hospital Universitário (HU) que se localiza na Av. Prof. Lineu Prestes, 2565 - Cidade Universitária- Fone: 3039-9468 e garantirão seu atendimento. Além disso, um médico estará presente nas dependências do Instituto do Sono durante todas as sessões experimentais.

\section{V - ENDEREÇOS E TELEFONES DOS RESPONSÁVEIS PELO ACOMPANHAMENTO DA PESQUISA:}

Este estudo será conduzido pela Profa. Lilian França Wallerstein, bacharel em Educação Física pela Escola de Educação Física e Esporte da USP e integrante do GEPAN (Grupo de Estudo e Pesquisa das Adaptações Neuromusculares ao Treinamento de Força) da mesma instituição, coordenado pelo pesquisador responsável desse projeto, Professor Doutor Carlos Ugriniwitsch. Em caso de necessidade o senhor (a) poderá entrar em contato com a Profa. Lilian França Wallerstein pelos telefones: 11 9154-8674/ 3935-3497, ou com o prof ${ }^{\circ}$ Carlos pelo telefone: 3091-2143.

\section{OBSERVAÇÕES COMPLEMENTARES}

Nenhuma 


\section{VII - CONSENTIMENTO PÓS-ESCLARECIDO}

Declaro que, após convenientemente esclarecido pelo pesquisador e ter entendido o que me foi explicado, consinto em participar do presente Projeto de Pesquisa.

São Paulo, de de 2008.

Assinatura do sujeito da pesquisa ou responsável legal.

Prof. Dr. Carlos Ugrinowitsch (pesquisador responsável). 


\section{ANEXO II - Mini Exame do Estado Mental}

Os idosos foram avaliados através do teste Mini Exame do Estado Mental MEEM (Mini Mental State Examination - MMSE), elaborado por FOLSTEIN, FOLSTEIN e McHUGH em 1975. É um questionário de fácil aplicação, traduzido para a língua portuguesa por BERTOLUCCI, BRUCKI, CAMPACCI \& JULIANO, (1994). Segundo BRUCKI, NITRINI, CARAMELLI, BERTOLUCCI, \& OKAMOTO (2003) esse teste sofre grande influência da escolaridade e deve ser adaptado, quanto aos escores, para a população de baixa escolaridade. Os escores utilizados para excluir os suspeitos de demência, de acordo com as adaptações para o grau de escolaridade serão:

- <20 para pessoas analfabetas;

- <25 para pessoas que estudaram de um a quatro anos;

- <27 para pessoas que estudaram de cinco a oito anos;

- <28 para pessoas que estudaram mais de nove anos.

NOME:

IDADE:

SEXO:

TEMPO DE ESTUDO (anos):

Material necessário: Você precisará de uma caneta esferográfica, um relógio de pulso, uma folha de papel e os cartões impressos 1 e 2.

Dê 10 segundos para cada resposta. Marque 1 ponto para cada resposta correta e 0 para as incorretas. Diga "Eu vou fazer algumas perguntas e dar alguns problemas para serem resolvidos. Por favor, tente responder da melhor forma que puder".

Q1. Orientação:

Dê um ponto em cada resposta correta. Em caso de dúvida, registre a resposta dada ao lado e contate o supervisor.

- Em que ano estamos?

- Em que mês estamos?

- Em que dia do mês estamos?

- Em que dia da semana estamos?

- Em que semestre nós estamos?

- Em que país nós estamos?

- Em que estado nós estamos?

- Em que cidade estamos?

- Em que bairro estamos?

Alternativa: "Em que rua estamos?

- Em que andar estamos?

No caso de casa térrea, pode ser usada a alternativa "Em que quarto estamos?"

PONTUAÇÃO TOTAL Q1: 


\section{Q2. Retenção - Registro de dados}

"Agora vou lhe dar o nome de três objetos. Quando eu terminar, pedirei que os repita em voz alta, em qualquer ordem. Guarde quais são, porque vou perguntar o nome deles de novo em alguns minutos".

Leia os nomes dos objetos devagar e de forma clara somente uma vez. O sujeito deve repeti-los em até 20". Dê um ponto por cada objeto lembrado e zero para os não lembrados, apenas na primeira tentativa. Se o sujeito não conseguir repetir todos os objetos:

1) Repita todos os objetos até que o entrevistado os aprenda (máximo de repetições: 5 vezes).

2) Anote o número de repetições que teve que fazer.

3) Nunca corrija a primeira tentativa.

CARRO

VASO

JANELA

Número de repetições

PONTUAÇÃO TOTAL Q2:

\section{Q3. Atenção e cálculo}

"Agora subtraia sete de 100 e continue subtraindo sete do restante".

Quando o indivíduo começar - não interrompa - permita que ele prossiga até que tenham sido feitas cinco subtrações. Se o indivíduo parar antes que cinco subtrações tenham sido feitas, repita a instrução original "por favor, continue subtraindo sete do restante" (máximo três vezes). Se o entrevistado errar alguma das subtrações, não corrija.

a)

\begin{tabular}{|l|l|l|l|l|l|}
\hline Resposta do indivíduo & & & & & \\
\hline Resposta correta & 93 & 86 & 79 & 72 & 65 \\
\hline
\end{tabular}

Pontuação em Q3a:

Como tarefa alternativa, pode-se pedir que o indivíduo soletre a palavra "MUNDO" de trás para frente. Dar-se-á um ponto para cada letra soletrada corretamente.

b)

\begin{tabular}{|l|c|c|c|c|c|}
\hline Resposta do indivíduo & & & & & \\
\hline Resposta correta & O & D & N & U & M \\
\hline
\end{tabular}

Pontuação em Q3b: 
Registre o total de respostas corretas Q3a ou Q3b abaixo.

Registrar apenas a tarefa de maior score.

PONTUAÇÃO Q3:

\section{Q4. Memória/evocação}

\section{"Agora me diga: Quais foram os três objetos que eu pedi para repetir agora há pouco?" \\ Dê 10 segundos para cada resposta. Marque um ponto para cada resposta correta independentemente da ordem.}

CARRO

VASO

JANELA

\section{PONTUAÇÃO Q4:}

Q5. Linguagem, Compreensão.

a) MOSTRE O RELÓGIO DE PULSO.

"Como é o nome disto?"

Nota:

Dê dez segundos para a resposta. Marque um ponto para a resposta certa. Aceite apenas "relógio de pulso", "relógio" ou "cronômetro".

b) MOSTRE A CANETA

"Como é o nome disto?"

Nota:

Dê dez segundos para a resposta. Marque um ponto para a resposta certa. Aceite apenas "caneta".

c) Agora quero que o (a) sr (a) repita esta frase depois de mim:

"Nem aqui, nem ali, nem lá".

Nota:

Fale as palavras com clareza. Dê dez segundos para a resposta. Marque um ponto para a repetição correta, que deve ser exata.

d) DÉ AO INDIVÍDUO O CARTÃO 1 COM A AFIRMAÇÃO "FECHE OS OLHOS"

Por favor, leia essa frase e faça o que está sendo pedido. Nota:

Se analfabeto, leia a frase para o entrevistado.

Dê dez segundos. Repita as instruções até três vezes se necessário. Marque um ponto apenas se o indivíduo fechar os olhos. 
e) DÊ AO INDIVÍDUO UM LÁPIS E UM PAPEL

"Escreva uma frase completa, de sua escolha, nesse pedaço de papel".

Nota:

Dê 30 segundos. Marque um ponto se a frase fizer sentido, isto é, tiver sujeito, verbo e objeto. Ignore os erros de ortografia.

PONTUAÇÃO TOTAL Q5:

\section{Q6. Habilidade Construtiva}

a) APRESENTE PARA O INDIVÍDUO O CARTÃO 2.

"Por favor, copie este desenho".

Nota:

Permita várias tentativas até que o indivíduo tenha terminado (no máximo um minuto). Marque um ponto se o indivíduo desenhou duas figuras com cinco lados, formando a intersecção destas uma figura de quatro lados (diamante, losango).

b) Observe com que mão o indivíduo segurou a caneta ou pergunte se ele é destro ou canhoto. Pegue um pedaço de papel em branco, segure-o na frente do indivíduo. Peça para o indivíduo prestar muita atenção. Você só poderá dar a instrução uma vez. Não é permitido repetir durante o transcurso da tarefa.

"Eu vou Ihe dar esta folha de papel. Quando eu o fizer o sr (a) vai pegar esta folha com sua mão direita/esquerda (mão oposta à que ele costuma usar), dobrar uma vez ao meio com as duas mãos e colocar no chão".

Dê 30 segundos. Marque um ponto para cada instrução executada de forma correta, máximo de três pontos.

Pegar com a mão não dominante Dobrar ao meio com as duas mãos Colocar no chão 
Cartão número 1:

FECHE OS OLHOS

Cartão número 2:

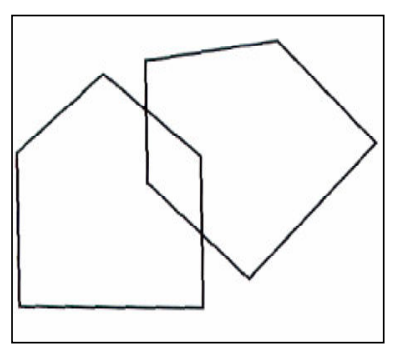




\section{ANEXO III - Escala de depressão}

Essa avaliação foi feita por meio de um questionário que contém dez itens dicotômicos que avaliam sintomas depressivos. Esse questionário foi utilizado no estudo de HOTATIAN (2002), que considerou como suspeitos de depressão os idosos que responderam a sete ou mais questões indicativas de estados depressivos. No nosso estudo, adotaremos os mesmos escores para exclusão dos sujeitos.

NOME:

IDADE:

SEXO:

Para cada uma das seguintes perguntas escolha a melhor resposta de como você tem se sentido na última semana:

\begin{tabular}{|c|c|}
\hline 1. Está satisfeito com a sua vida? & $\begin{array}{lll}\text { NÃO } & \ldots \ldots \ldots . . . & 0 \\
\text { SIM } & \ldots \ldots \ldots . . .1 \\
\end{array}$ \\
\hline 2. Sente-se frequentemente chateado ou desanimado? & $\begin{array}{lll}\text { NÃO } & \ldots \ldots \ldots . . . & 0 \\
\text { SIM } & \ldots \ldots \ldots . . . & 1 \\
\end{array}$ \\
\hline 3. Sente-se frequentemente sem esperança? & $\begin{array}{l}\text { NÃO } \ldots \ldots \ldots . . . \\
\text { SIM } \ldots \ldots \ldots . .1\end{array}$ \\
\hline 4. Prefere ficar em casa a sair ou fazer coisas novas? & $\begin{array}{l}\text { NÃO } \ldots \ldots \ldots . . .10 \\
\text { SIM } \ldots \ldots \ldots . .1\end{array}$ \\
\hline 5. Sente-se sem valor ou inútil? & $\begin{array}{l}\text { NÃO } \ldots \ldots \ldots . . . \\
\text { SIM } \ldots \ldots \ldots . .1\end{array}$ \\
\hline 6. Tem sentido pouco prazer nas coisas? & $\begin{array}{l}\text { NÃO } \ldots \ldots \ldots . . . \\
\text { SIM } \ldots \ldots \ldots . .1 \\
\end{array}$ \\
\hline 7. Tem se sentido mais "nervosos"? & $\begin{array}{l}\text { NÃO } \ldots \ldots \ldots . . . \\
\text { SIM } \ldots \ldots \ldots . .1\end{array}$ \\
\hline 8. Tem se preocupado mais ultimamente? & $\begin{array}{lll}\text { NÃO } & \ldots \ldots \ldots . . . & 0 \\
\text { SIM } & \ldots \ldots \ldots . . . & 1 \\
\end{array}$ \\
\hline 9. Tem apresentado emagrecimento? & $\begin{array}{lll}\text { NÃO } & \ldots \ldots \ldots . . . & 0 \\
\text { SIM } & \ldots \ldots \ldots \ldots & 1 \\
\end{array}$ \\
\hline 10. Tem sentido dificuldade para dormir? & $\begin{array}{l}\text { NÃO } \ldots \ldots \ldots . . . \\
\text { SIM } \\
\end{array}$ \\
\hline
\end{tabular}




\section{ANEXO IV - Avaliação médica (anamnese)}

Com a qual o médico avaliava os fatores de risco do sujeito juntamente com os exames clínicos realizados e exames trazidos. Essa anamnese foi montada em conjunto com o médico responsável pela avaliação dos sujeitos do estudo, Dr. Luiz Augusto Riani Costa.

PROJETO EXERCÍCIO FÍSICO - USP - ANAMNESE

Nome:

ID:

Data:

Endereço: Número:

Complemento: Bairro: CEP:

Data de Nascimento:

Tel Residencial: 1

Tel do plano de saúde:

Grau de Escolaridade: Raça:

1. Você costuma sentir:

( ) Tontura.

( ) Falha no coração.

( ) Desmaios.

( ) Escurecimento da vista.

( ) Dor no peito.

( ) Taquicardia (batedeira no peito).

( ) Falta de ar (canseira no peito, cansa fácil).

2. Você tem problema cardíaco (ataque, cirurgia ou doença cardíaca)?

( ) Não ( ) Sim. Qual?

3. Sexo: Idade: anos.

4. Você possui pais, irmãos ou avós que tiveram ou têm problemas cardíacos?

( ) Não ( ) Sim. Quem? O quê?

5. Você possui pais, irmãos ou avós que têm hipertensão?

( ) Não （） Sim. Quem?

6. Você possui pais, irmãos ou avós que têm diabetes mellitus?

( ) Não ( ) Sim. Quem?

7. Você tem hipertensão?

( ) Não ( ) Sim 
8. Você tem diabetes mellitus?

( ) Não ( ) Sim

9. Você tem colesterol alto?

( ) Não ( ) Sim

10. Você é fumante?

( ) Não ( ) Sim ( ) Ex-fumante. Parou há quanto tempo?

11. Você possui algum tipo de problema mioarticular (lesão de natureza articular ou muscular, por exemplo: Artrite, artrose, dores musculares constantes, etc.)? ( ) Não ( ) Não sei （） Sim. Descreva:

12. Você possui algum tipo de problema ósseo, como osteopenia ou osteoporose? ( ) Não ( ) Sim

13. Você já teve alguma fratura?

( ) Não ( ) Sim. Local (s) da fratura? A quanto tempo?

14. Você possui outros problemas de saúde?

( ) Não ( ) Sim. Quais?

15. Você já passou por algum procedimento cirúrgico?

( ) Não ( ) Sim. Qual?

16. Você toma algum remédio?

( ) Não ( ) Sim. Qual?

17. Com que idade ocorreu sua ultima menstruação? anos.

18. Você faz uso de medicamentos para reposição hormonal?

( ) Não ( ) Sim. Quais?

19. Você tem alguma limitação para realizar os seus movimentos da vida diária? ( ) Não ( )Sim. Quais?

20. Você tem tremores nas mãos para realizar atividades que exijam coordenação (ex. beber café)?

( ) Não ( ) Sim. 
21. Algum médico recomendou que você fizesse exercício?

( ) Não ( ) Sim

22. Algum médico já disse que você tem alguma limitação para o exercício?

( ) Não ( ) Sim Qual?

23. Você anda, corre ou nada regularmente?

( ) Não （） Sim. Há quanto tempo? Quantos dias por semana? Quantos minutos por dia?

24. Você faz outras atividades físicas regulares?

( ) Não ( ) Sim. Quais? Há quanto tempo? dias por semana? Quantos minutos por dia? Quantos

Dados para preenchimento da equipe de avaliação:

\begin{tabular}{|c|c|c|c|c|c|c|c|c|c|}
\hline & \multirow{2}{*}{$\begin{array}{c}\text { PA } \\
\text { Clínico }\end{array}$} & \multirow[t]{2}{*}{ Peso } & \multirow[t]{2}{*}{ Altura } & \multicolumn{2}{|c|}{$1^{\text {a } P A}$} & \multicolumn{2}{|c|}{$2^{\mathrm{a}} \mathrm{PA}$} & \multicolumn{2}{|c|}{ Média PA } \\
\hline & & & & DIR & ESQ & DIR & ESQ & DIR & ESQ \\
\hline Data & 11 & I & I & & I & I & & & ---- \\
\hline Valor & l & & & l & 1 & I & I & I & 1 \\
\hline
\end{tabular}

\begin{tabular}{|l|c|c|c|c|}
\hline \multirow{2}{*}{} & \multicolumn{5}{|c|}{ Teste Esforço Máximo } \\
\cline { 2 - 5 } & PA & Peso & Altura & IMC \\
\hline Data & $/$ & $/$ & & \\
\hline Valor & $/$ & & & \\
\hline
\end{tabular}

\begin{tabular}{|l|c|c|}
\hline & Demência & Depressão \\
\hline Data & \multicolumn{2}{|c|}{$/$} \\
\hline Presente & & \\
\hline Ausente & & \\
\hline
\end{tabular}

\section{SITUAÇÃO:}

( ) Incluído. ( ) Excluído. Motivo:

( ) Finalizou protocolo. ( ) Não finalizou protocolo.

Motivo:

\begin{tabular}{|l|l|l|l|l|l|l|l|l|l|l|}
\hline 1 $^{\text {a }}$ PA & OST & IMC & DCC & Q1 & Q2 & Q3 & ATIV FíSICA & 2 $^{\text {a PA }}$ & CONS & ERGS \\
\hline & & & & & & & & & & \\
\hline
\end{tabular}

